\begin{abstract}
UNIVERSIDADE DE SÃO PAULO
ESCOLA DE ARTES, CIÊNCIAS E HUMANIDADES

PROGRAMA DE PÓS-GRADUAÇÃO EM CIÊNCIAS DA ATIVIDADE FÍSICA
\end{abstract}

DÉBORA NAVARRO ROCHA

Significado das ações de promoção da saúde e atividade física de adolescentes do ensino médio no município de Campo Largo (PR) 


\title{
DÉBORA NAVARRO ROCHA
}

Significado das ações de promoção da saúde e atividade física de adolescentes do ensino médio no município de Campo Largo (PR)

\author{
Versão original
}

Dissertação apresentada à Escola de Artes, Ciências e Humanidades da Universidade de São Paulo para obtenção do título de Mestre em Ciências pelo Programa de PósGraduação em Ciências da Atividade Física.

Área de Concentração: Atividade física e promoção da saúde

Orientador: Prof. Dr. Douglas Roque Andrade 
Autorizo a reprodução e divulgação total ou parcial deste trabalho, por qualquer meio convencional ou eletrônico, para fins de estudo e pesquisa, desde que citada a fonte.

Rocha, Débora Navarro

Significado das ações de promoção da saúde e atividade física de adolescentes do ensino médio no município de Campo Largo (PR) / Débora Navarro Rocha ; orientador, Douglas Roque Andrade. - 2017 $74 \mathrm{f}$.

Dissertação (Mestrado em Ciências) - Programa de PósGraduação em Ciências da Atividade Física, Escola de Artes, Ciências e Humanidades, Universidade de São Paulo, São Paulo Versão original

1. Atividade física - Campo Largo (PR). 2. Jovens - Campo Largo (PR). 3. Promoção da saúde - Campo Largo (PR). 4. Educação física escolar - Campo Largo (PR). I. Andrade, Douglas Roque, orient. II. Título 
Nome: NAVARRO ROCHA, Débora

Título: Significado das ações de promoção da saúde e atividade física de adolescentes do ensino médio no município de Campo Largo (PR)

Dissertação apresentada à Escola de Artes, Ciências e Humanidades da Universidade de São Paulo para obtenção do título de Mestre em Ciências pelo Programa de PósGraduação em Ciências da Atividade Física.

Área de Concentração:

Atividade física e promoção da saúde

Aprovado em:

\section{Banca Examinadora}

Prof. Dr.

Julgamento:

Prof. Dr.

Julgamento:

Prof. Dr.

Julgamento:
Instituição:

Assinatura:

Instituição:

Assinatura:

Instituição:

Assinatura: 
Dedico esse trabalho a minha mãe Cecília, nenhum título acadêmico me trás tanta admiração quanto a que sinto por você. 


\section{AGRADECIMENTOS}

Aos meus alunos, por me permitirem entrar nas suas vidas. Tenho verdadeira adoração por nossos momentos e jovialidade que me proporcionam, são vocês os grandes responsáveis pela leveza de minha vida;

Ao meu orientador Douglas, por me propiciar a honra de ser sua primeira orientanda de Mestrado;

Aos professores Marilia Velardi e Aylton José Figueira Junior pelas contribuições oferecidas no exame de qualificação;

À minha mãe, irmã, Bruno, Caique, Valentina e Helena, minha família e minha maior representação do que é o amor;

Ao Instituto Federal do Paraná, não tem um dia que não agradeço por trabalhar nessa Instituição de Ensino, o maior orgulho de minha vida;

À Escola de Artes Ciências e Humanidades da Universidade de São Paulo, por trazer São Paulo novamente a minha vida, estava com saudades. 


\section{RESUMO}

NAVARRO ROCHA, Débora. Significado das ações de promoção da saúde e atividade física de adolescentes do ensino médio no município de Campo Largo (PR). 2017. 74 f. Dissertação (Mestrado em Ciências) - Escola de Artes, Ciência e Humanidades, Universidade de São Paulo, São Paulo, 2017.

Essa pesquisa foi desenvolvida com o objetivo de analisar o significado que os adolescentes atribuem às estratégias de promoção da saúde e da atividade física no ambiente escolar e comunitário. Para tanto, realizamos uma pesquisa qualitativa, descritiva, de caráter exploratório com adolescentes de ambos os sexos do Instituto Federal do Paraná, município de Campo Largo (PR). A primeira etapa consistiu na aplicação de um questionário com questões abertas e a segunda por discussões em grupo sobre os temas: "atividade física na escola e na comunidade" e "saúde na escola e na comunidade”. A análise dos dados foi realizada de maneira qualitativa, onde as informações obtidas no questionário e nas discussões foram analisadas com o emprego da análise de conteúdo. Os achados referentes à análise do material documental das aulas de educação física escolar proposta por essa pesquisa demostraram que os estudantes significam atribuem o significado a saúde como condição atrelada às suas responsabilidades, oriundas especificamente dos determinantes biológicos como hábitos alimentares e práticas de atividades físicas; no entanto destacam-se as associações que realizam entre saúde e autopercepções positivas. Com vistas à promoção de saúde e da atividade física, os estudantes sugerem que à escola e à comunidade lhes cabem o papel de incentivá-los, demonstram decepção pela ausência de ações que tornam a escola mais dinâmica, apresentam entusiasmo ao identificar e explicar os espaços e ações que são familiarizados e esperam o desenvolvimento de conteúdos relacionados à saúde através de novas metodologias, principalmente as relacionadas às mídias.

Palavras-chave: Participação social. Promoção da Atividade Física. Promoção da Saúde. 


\begin{abstract}
NAVARRO ROCHA, Débora. Significance of actions to promote health and Physical activity of high school adolescents in the city of Campo Largo (PR). 2017. 74 p. Dissertation (Master of Science) - School of Arts, Sciences and Humanities, University of São Paulo, São Paulo, 2017. Original version.

This research was developed with the purpose of analyzing the meaning that the adolescents attribute to the strategies of health promotion and physical activity in the school and community environment. To do so, we conducted a qualitative, descriptive, exploratory study with adolescents of both sexes from the Federal Institute of Paraná, Campo Largo (PR). The first step consisted of the application of a questionnaire with open questions and the second by group discussions on "physical activity in school and community" and "health in school and community". Data analysis was carried out in a qualitative way, where the information obtained in the questionnaire and the discussions were analyzed using content analysis. The findings related to the analysis of the documentary material of the school physical education classes proposed by this research showed that the students mean that they attribute the meaning to health as a condition linked to their responsibilities, specifically derived from biological determinants such as eating habits and physical activity practices; however, the associations that perform between health and positive self-perceptions stand out. In order to promote health and physical activity, the students suggest that the school and the community have the role of encouraging them, they show disappointment in the absence of actions that make the school more dynamic, they are enthusiastic in identifying and explaining spaces and actions that are familiar and expect the development of health-related content through new methodologies, especially those related to the media.
\end{abstract}

Keywords: Social participation. Promotion of Physical Activity. Health promotion 


\section{Sumário}

1 APRESENTAÇÃO

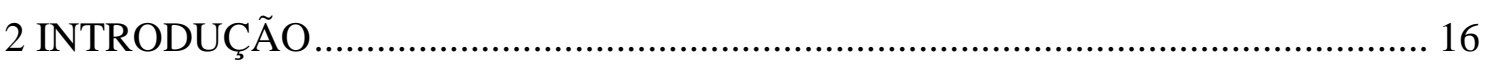

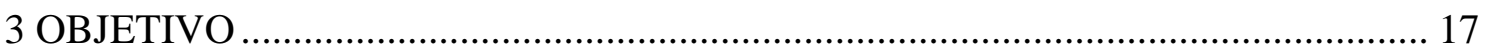

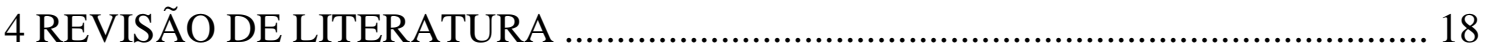

4.1 PADRÕES DE ATIVIDADE FÍSICA E SEUS FATORES DETERMINANTES ............... 18

4.2 O PAPEL DA ESCOLA NA PROMOÇÃO DE SAÚDE …............................................... 20

4.3 PRIMEIROS PASSOS À UTOPIA DE SER UMA ESCOLA PROMOTORA DA SAÚDE

24

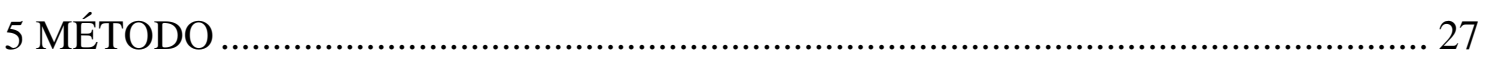

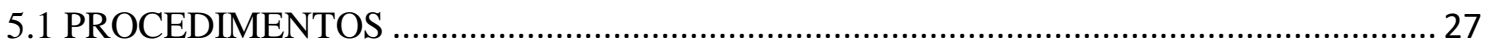

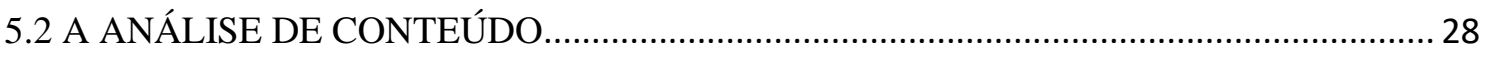

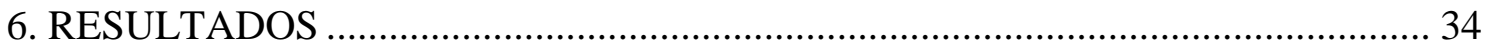

6.1 PROMOÇÃO DE ATIVIDADES FÍSICA NA ESCOLA E NA COMUNIDADE .............. 34

6.2 PROMOÇÃO DA SAÚDE NA ESCOLA E NA COMUNIDADE ....................................... 46

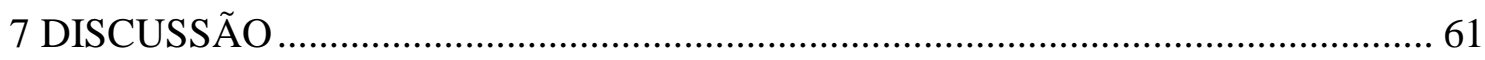

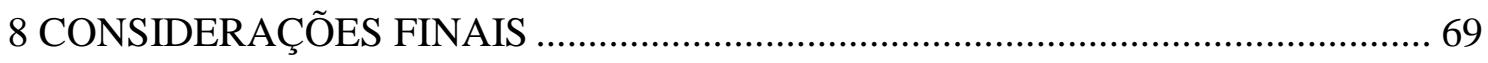

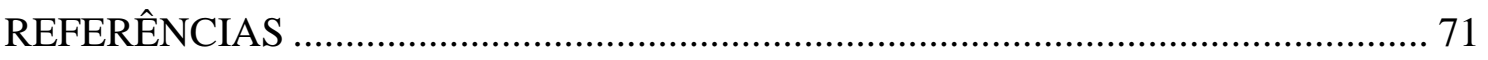

ANEXO A - QUESTIONÁRIO DE PROMOÇÃO DE SAÚDE E ATIVIDADE

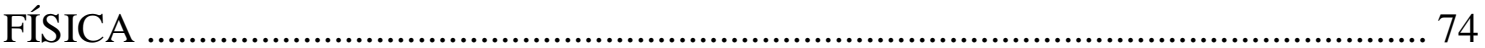




\section{APRESENTAÇÃO}

Desde os meus 3 anos de idade eu danço. Vivencio momentos felizes sempre iniciando com um pliè. Adolescente, só me imaginava exercendo uma profissão em que eu pudesse continuar me expressando dessa forma, e assim, impetuosamente e sem grandes conhecimentos sobre, entrei em 2001 no curso de Licenciatura Plena em Educação Física da Universidade Estadual de Londrina.

Nenhuma sapatilha de ponta foi tão dolorosa quanto à constatação de minha ineficiência motora com as inúmeras bolas, que centralizavam a grande maioria das disciplinas que compunha o curso, e assim, por questões de sobrevivência emocional, me dediquei às disciplinas que não exigiam tanto minha aptidão física esportiva, principalmente as relacionadas à Ciência da Saúde, e Educação Escolar, que me foram agradabilíssimas.

Iniciei minha vida profissional e minha trajetória como professora de educação física em 2006, pela secretaria de educação do estado de São Paulo, em Itaju, uma cidade de 2000 habitantes, em sua única escola, a Escola Estadual Professor Erasto Castanho de Andrade.

Minha primeira lembrança foi um primeiro contato com um estudante, em que ele me chamou de dona. Eu tinha 23 anos e um menino de 13 anos me chamou de dona, ri sem jeito, sem entender algo que naquela região era comum, chamarem os mais velhos e assim suas professoras, de dona.

Eu mal era dona de mim e de um dia para outro me transformei na "dona" de educação física de simplesmente todas as crianças e adolescentes em idade escolar da cidade, lembro-me de caminhar pelas ruas e simplesmente reconhecer todos aqueles rostos juvenis, acenar e cumprimentar com frequência e me deparar pela primeira vez com a sensação de ser carinhosamente observada por aquelas crianças e seus familiares em seus portões.

Entrar naquela escola e lidar com a vida daquela comunidade foi o primeiro momento em que dei conta de quão privilegiada havia sido a minha, e que abissal era a distância entre minha formação acadêmica e a realidade daquela, e porque não, de todas as escolas.

Fiquei um ano em Itaju nos primeiros passos do aprendizado de ser professora, conto com a sensação de ter aprendido mais do que ensinado, e apesar das inerentes 
falhas, sorrio com a maior e melhor das lembranças, de ali ter me apaixonado pela minha profissão e pelos estudantes.

Por estar distante de minha cidade natal, Bauru, em 2007 pedi remoção para lá, e me tornei professora de umas das últimas escolas estaduais de $1^{\mathrm{a}}$ a $4^{\mathrm{a}}$ séries do ensino fundamental que ainda não haviam sido municipalizadas, nunca mais fui chamada de dona, mas passei a ser carinhosamente chamada de tia.

Apesar de estar em um dos bairros mais perigosos e violentos de Bauru, a Escola Estadual Parque Jaraguá, tão bem organizada e reconfortante, parecia estar numa redoma onde nada de ruim acontecia me causando extrema satisfação e saudades.

Após três anos ali, exonerei de meu cargo, fui trabalhar e estudar em Portugal, e quando voltei, atuei por três anos como docente do ensino superior, na Universidade Estadual de Ponta Grossa, e nas Faculdades Integradas de Itararé, algo que me distanciou da educação física escolar.

Essa retomada se deu com minha aprovação no Instituto Federal de Educação, Ciência e Tecnologia do Paraná (IFPR), na cidade de Foz do Iguaçu, no dia 15 de agosto de 2012.

O IFPR é uma instituição pública federal de ensino, que tem por finalidade, entre outras, ofertar a educação profissional e tecnológica, em todos os seus níveis e modalidades, formando e qualificando cidadãos com vistas à atuação profissional nos diversos setores da economia, com ênfase no desenvolvimento socioeconômico local, regional e nacional, conforme estabelece o artigo $6^{\circ}$, inciso I, da Lei ${ }^{\circ} 11.892 / 2008$.

O campus Foz do Iguaçu conta com uma estrutura impecável, pois está localizado onde antigamente era o clube social dos funcionários da Itaipu binacional, doado para ser transformado no IFPR; a minha prática docente contava, portanto, com uma estrutura repleta de quadras, piscinas, campos e espaços além do almejado para aulas de educação física. Porém, por motivos pessoais, fui removida à cidade de Campo Largo, região metropolitana de Curitiba e me deparei com um câmpus mais novo e em desenvolvimento.

O IFPR Campo Largo iniciou suas atividades em 24 de maio de 2010, como núcleo avançado do câmpus Curitiba, em 05/12/2012 a unidade deixou de ser um núcleo avançado e passou ao status de câmpus, atualmente conta com 674 discentes, 55 docentes, e 29 técnicos administrativos.

Dentre os cursos ofertados, dois são de ensino médio integrado ao técnico, o curso técnico em eletromecânica, iniciado no ano de 2014, e o curso técnico em 
automação, iniciado em 2016, ambos na modalidade presencial, com duração de 4 anos, em oferta integral, e contam com 139 e 78 estudantes respectivamente.

Até o presente momento inexistem espaços próprios para as aulas de educação física bem como para momentos de lazer e atividade física, e nesse contexto, minhas aulas, até o ano letivo de 2016, em sua grande maioria foram teóricas, direcionadas à manutenção e à preservação da saúde, numa perspectiva de educação para a saúde.

A linha de educação para a saúde foi apresentada durante minha graduação como um refrigério; por mais que no contexto de minha formação havia disciplinas maravilhosas em que ocorriam debates e críticas sobre o modelo de educação física escolar esportivista, ainda era essa a nossa grande realidade e para mim uma grande dificuldade, visto que durante minha infância e adolescência me dediquei à dança e às ginásticas e quando graduanda, me deparar com literalmente aulas de como aprender determinados esportes e ser avaliada pela minha execução foi árduo e desestimulante.

Através da sensação de inadequação à maioria das disciplinas que estudava, a leitura que fazia dessa linha e o contato com as riquíssimas aulas do professor Dartagnan Pinto Guedes, muitas de minhas dúvidas e anseios sobre o componente curricular educação física foram respondidos, e eu encontrei a forma como gostaria de desenvolver a educação física na escola.

Nessa perspectiva a educação para a saúde deverá ser alcançada mediante
interação de ações que possam envolver o próprio homem mediante suas
atitudes frente às exigências ambientais representadas pelos hábitos
alimentares, estado de estresse, opções de lazer, atividade física, agressões
climáticas, etc. Dessa forma, parece evidente que o estado de ser saudável
não é algo estático. Pelo contrário, torna-se necessário adquiri-lo e construi-lo
de forma individualizada constantemente ao longo de toda a vida, apontando
para o fato de que saúde é educável e, portanto deve ser tratada não apenas
com base em referenciais de natureza biológica e higienista, mas sobretudo
em um contexto didático pedagógico (Guedes, 1999).

O artigo e a bibliografia de onde o trecho citado acima foi extraído foram apreciados, relidos e incorporados inúmeras vezes às minhas falas, aulas, projetos e principalmente, às minhas atitudes frente à educação física, pois até o momento eu selecionava para minhas aulas, conteúdos que pensava serem oportunos aos estudantes para não apenas assimilarem a importância de serem adolescentes com hábitos de vida saudáveis, mas que os mantivessem além dos períodos de escolaridade.

No entanto, o curso de mestrado do programa de pós-graduação em Ciências da Atividade Física da Escola de Artes, Ciências e Humanidades da Universidade de São Paulo, na linha de pesquisa atividade física na promoção da saúde, me possibilitou verificar que em muitos momentos a maneira como interpretava e lidava com a 
educação para a saúde, era em muitos momentos autoritária, presa no modelo médico de prevenção de doenças que aponta os indivíduos como os únicos responsáveis pelo seu estado de saúde e essa retomada de consciência foi assustadora.

Esse momento de repensar minha prática docente ocorreu em paralelo aos primeiros passos do desenvolvimento do primeiro curso de ensino médio no campus Campo Largo, o técnico em eletromecânica, curso que atuava como professora de educação física e no cargo de coordenadora pedagógica que representei durante os anos de 2014, 2015 e 2016.

Esse momento naturalmente levantou meu tema de pesquisa, que seria trazer as ideias e debates dos meus estudantes sobre a promoção da saúde e da atividade física.

Essas discussões já haviam iniciado discretamente pela gestão que eu fazia parte, especificamente nas reuniões do Conselho de Representante de Turmas - CRT, e os Coletivos Pedagógicos bimestrais, momentos que visam promover a discussão de assuntos pertinentes ao segmento discente, com vistas à promoção de decisões coletivas.

Quando esses diálogos se tornaram mais frequentes, iniciou um movimento dos próprios estudantes frente à necessidade de adaptar os espaços que tínhamos no campus para as aulas e práticas de atividades físicas. Através de uma mobilização de estudantes e servidores, um antigo galpão que estava sendo inutilizado foi adaptado e ali desenvolvidas uma quadra de vôlei, uma de basquete e foi colocada uma mesa de tênis de mesa. Esse galpão, mesmo sendo um espaço ermo, com buracos no teto que impossibilitam a utilização do local em épocas de chuva e com uma iluminação muito fraca para as práticas após o entardecer, passou a ser frequentemente utilizado pelos estudantes.

Encontrei-me, portanto, no momento de ser a professora de educação física em um local que necessita de transformações físicas para propiciar aos estudantes uma educação plena e de qualidade, com uma profunda necessidade de repensar minha atuação e com o estímulo de desenvolver minha dissertação.

O campus conta com a promessa da construção de um ginásio esportivo, bem como de outras reformas necessárias desde o ano de 2014, no entanto, com essa atual conjectura político-econômica, em especial a rede federal e tecnológica de ensino, não temos alternativa a não ser repensar nossos planos principalmente quanto aos espaços. O país sofre os efeitos da recessão que castiga o país desde 2014, consequência do colapso fiscal e da explosão dos gastos públicos. A longa crise política alimenta a incerteza econômica; a política monetária de juros elevados, necessária para financiar a 
dívida pública, inibe os ânimos de investidores, empresários e consumidores. Resultado: a arrecadação federal vem caindo e a recuperação tem sido tímida. O colapso das contas públicas determinou severo corte de gastos, que atingiu a educação em cheio. Quando os efeitos da PEC dos gastos atingirem a educação em 2018, o temor é que soframos regressões ainda maiores em políticas que têm enfrentado a notória desigualdade social.

Ou seja, momento oportuno para debater nossa escola enquanto um espaço que subsidie a prática educativa para a saúde, possibilitando identificar demandas, desejos, desafios, bem como a forma como os adolescentes visualizam seus cotidianos, para, num cenário de realizações, caminhar na direção de compreender e trabalhar as questões do estilo de vida em articulação com as condições reais de suas vidas.

Ao relembrar as reações de meus estudantes, que muito se interessam pelos temas relacionados à saúde, percebo que por mais que se interessem e identifiquem a importância de serem fisicamente ativos e adotarem um estilo de vida saudável, seus argumentos são francamente compostos de desânimo, se sentem derrotados e inaptos para tal estilo de vida, noto pelas suas falas que sou vista como aquela pessoa que faz tudo certo em relação aos meus próprios hábitos saudáveis, que ensino sobre como deveria ser, mas que por fim, para a realidade deles, apresento uma frustrante proposta.

Durante essas reflexões, a adaptação do galpão e o início da escrita do meu projeto de pesquisa, desenvolvi como atividade de educação física, com a turma do $3^{\circ}$ ano, uma proposta de projetos de práticas esportivas monitorados pelos estudantes que se interessassem, e assim organicamente, iniciaram-se treinos de futsal em um dos parques da cidade, basquete, tênis de mesa e vôlei no galpão.

Essas atividades ocorrem no mínimo uma vez na semana e são conduzidas completamente pelos estudantes, que se organizam, se responsabilizam pelos materiais emprestados, controlam a frequência dos colegas e inclusive marcam jogos com outras instituições, não têm qualquer intervenção minha, a não ser conversas informais sobre seus andamentos e convites que recebo para os jogos que marcam.

Disso surgiram questões como quais são os conhecimentos, as habilidades, os valores, as modificações e ações que deveriam veicular em um processo de ensinoaprendizagem para a saúde num ambiente escolar? Quem são os adolescentes dessa escola? Suas expectativas? Como foram suas experiências anteriores em relação à saúde na escola e o que gostariam de experimentar são partes integrantes que estimulam o desenvolvimento desse trabalho.

Esses acontecimentos, minha atuação na coordenação e as luzes que as 
orientações do projeto me deram, se misturaram e surgiram concomitantemente com o alinhamento de meu problema de pesquisa e com o objetivo de analisar o significado dos adolescentes sobre como devem ser as estratégias de promoção da saúde e da atividade física no ambiente escolar e comunitário no momento em que nos encontramos, através do conhecimento de suas demandas, aspirações e dificuldades, que enfrentam em relação à promoção da saúde. 


\section{INTRODUÇÃO}

A inatividade física é um dos maiores problemas de saúde pública e a escola no seu papel de fomentar os diversos processos de ensino aprendizagem, torna-se protagonista à promoção da saúde, com o papel de aproximar as ações em Educação para a Saúde e os cotidianos dos adolescentes.

Ao fazer uma revisão bibliográfica sobre os estudos que desenvolveram programas de promoção de saúde escolar com participações da população alvo em todo o planejamento, é notória a escassez de estudos atuais, porém os que foram encontrados destacam-se pela compreensão e trabalho com as questões do estilo de vida em articulação com as condições reais de vida dos adolescentes.

Dessa forma, ao considerar o princípio teórico do modelo ecológico de promoção de saúde que entende que a saúde é determinada por uma complexa relação entre fatores ambientais, organizacionais e pessoais e que sua promoção corresponde a medidas gerais e educativas, que objetivam melhorar a resistência e o bem-estar geral dos indivíduos (comportamentos alimentares, não ingestão de drogas, tabaco, exercício físico e repouso, contenção de estresse), esses indivíduos devem receber orientações para cuidar do ambiente para que este não favoreça o desenvolvimento de agentes etiológicos, (comportamentos higiênicos relacionados à habitação e entornos).

A escola, na totalidade de seu papel social tem a possibilidade de ser um espaço eficiente à compreensão e aproximação das questões do estilo de vida em articulação com os cotidianos dos adolescentes

Mediante a informação de que a inatividade tende a aumentar com a idade e que é um fator de risco às principais causas de mortalidade da população, identificar as barreiras e as percepções dos adolescentes torna-se primordial na obtenção de informações ao desenvolvimento de eficientes programas de intervenção e promoção da saúde.

Mesmo com os resultados positivos e pontuais de tais intervenções, são poucos os estudos que lidam e dão voz aos adolescentes, suas demandas, suas dificuldades e seus significados sobre a divulgação de informações referentes aos comportamentos de saúde. 


\section{OBJETIVO}

Analisar o significado que os estudantes do Instituto Federal do Paraná, campus Campo Largo atribuem às estratégias de promoção da saúde e da atividade física no ambiente escolar e comunitário. 


\section{REVISÃO DE LITERATURA}

\subsection{PADRÕES DE ATIVIDADE FÍSICA E SEUS FATORES DETERMINANTES}

Está bem estabelecida a relação entre os benefícios da adoção de um estilo de vida ativo e a promoção de saúde. Dentre os inúmeros benefícios fisiológicos como redução de morbidades e mortalidade (LEE; SHIROMA; LOBELO, 2012), ser fisicamente ativo está associado à redução do risco de depressão, níveis mais elevados de autopercepções físicas e melhoria nos níveis de bem-estar mental e do humor (THØGERSEN-NTOUMANIS; FOX; NTOUMANIS, 2005).

Ao realizar um panorama sobre as causas de morbidades e mortalidades brasileira, Schmidt et al. (2011) reconhecem que as doenças crônicas não transmissíveis são responsáveis por $72 \%$ das causas de mortes no Brasil, dado que reflete as crescentes mudanças ambientais, epidemiológicas, demográficas, tecnológicas e nutricionais das últimas décadas, transformando profundamente a maneira como interagimos com o ambiente.

A inatividade física causa de 6 a 10\% da maioria das doenças coronárias, diabete tipo 2 e câncer de cólon e mama, reflete também 9\% de mortes prematuras, equiparando-se aos efeitos do tabaco e da obesidade. É identificada como o quarto principal fator de risco às doenças não transmissíveis e responsável por mais de três milhões de mortes prematuras no mundo (LEE; SHIROMA; LOBELO, 2012).

Um levantamento com informações de 122 países (representando 88,9\% da população mundial) identificou que $31 \%$ dos adultos são fisicamente inativos e $80 \%$ dos adolescentes fazem menos do que os 60 minutos de atividade física de moderada a vigorosa intensidade recomendados diariamente (HALLAL et al., 2012).

Bauman et al. (2012) através de uma metanálise sobre os determinantes da atividade física, reportaram que crianças, adolescentes e adultos de países em desenvolvimento, têm níveis insuficientes de atividade física, e que esses números têm um crescimento exponencial apesar de conhecidas as inúmeras estratégias para melhorar esse quadro; encontraram também fortes associações com fatores psicológicos (auto eficácia), com culturais e sociais (suporte familiar e social) e nenhuma associação com o índice de massa corporal (IMC).

Wang, Wu, Liu (2003) identificaram que atividades físicas em momentos de lazer são realizadas mais frequentemente por jovens adultos, homens, pessoas de alto 
nível educacional, e por pessoas que moram próximas aos espaços públicos propícios às atividades físicas.

Com o objetivo de promover a atividade física no âmbito escolar, estudos de intervenção no Brasil apontaram efetividade na redução da inatividade física, no aumento da prática do deslocamento ativo e de exercícios de força e nas melhorias das práticas alimentares (BARROS et al., 2009; RIBEIRO; FLORINDO, 2010; DUCA et al., 2014).

No entanto, ao deparamos com esse contexto em que a inatividade aumenta com a idade, é maior entre o sexo feminino, em países desenvolvidos e tem um expressivo aumento nos países em desenvolvimento (HALLAL et al., 2012), torna-se necessário pensar sobre a promoção de saúde e da atividade física além do engessado processo saúde-doença, pois apesar de bem conhecidos os benefícios de se adotar um estilo de vida saudável, sua complexidade está relacionada às delicadas questões sobre estilos de vida, hábitos prejudiciais à saúde, aspectos socioeconômicos, educacionais, culturais e políticos.

Essa complexidade, oriunda de uma relação dinâmica com o ambiente indica que os determinantes da atividade física podem ser de origem individual (fatores psicológicos e biológicos), interpessoal (suporte social, práticas e normas culturais), ambiental (ambiente social, construído e natural), de políticas públicas (sistema de transporte, planejamento urbano, parques e setores de recreação, planos nacionais de atividade física, etc.) e de aspectos globais (desenvolvimento econômico, normas culturais e sociais, mídia, urbanização) (BAUMAN et al., 2012).

Assim, partimos de uma premissa de que precisamos nos aproximar das influências que contribuem à adoção de um estilo de vida mais saudável, para promover intervenções com melhores chances de sucesso, não apenas no momento em que ocorrem, mas por toda a vida das pessoas.

Em relação aos adolescentes da atualidade, que possuem um prospecto de uma crescente inatividade física, é de extrema importância lidar com o dado de que os fatores "psicológicos, cognitivos e emocionais" e "culturais e sociais" se destacam como os maiores impeditivos das práticas de atividade física e que o suporte social influencia a um estado de saúde mais positivo, qualidade de vida, bem-estar, autorrealização, menos sintomas físicos, de depressão e estresse.

A escola torna-se um ambiente favorável para que discussões sobre a promoção de saúde aconteçam e que os estudantes se sintam atuantes e coerentes com suas 
necessidades e que esse espaço promova conhecimento, amparo social e autonomia na escolha na adoção de um estilo de vida saudável.

\subsection{O PAPEL DA ESCOLA NA PROMOÇÃO DE SAÚDE}

Num contexto em que os determinantes da saúde vão além da reducionista concepção médico-curativa, que considera os indivíduos os únicos responsáveis pela sua condição de saúde, surge um movimento em 1974, no Canadá, marcado pela divulgação do documento "A new perspective on the health od Canadians", também conhecido como Relátório Lalonde, que prioriza a saúde como um direito passível de ser atingido através de uma elaborada produção social, de ações intersetoriais, como a educação, lazer, alimentação, saneamento básico entre outros, culminando em um novo paradigma à saúde pública, a Promoção da Saúde e a concepção de seus princípios.

Por conseguinte, durante a I Conferência Internacional de Promoção de saúde realizada em Ottawa, Canadá em 1986, foi divulgada a Carta de Otawa, que direcionou a Promoção da Saúde como um processo de capacitação e de fortalecimento das populações para melhorar suas condições de saúde, aumentar o seu controle sobre as mesmas e melhorar os fatores determinantes e condicionantes da saúde (BRASIL, 2001).

Entre as estratégias ali formuladas e confirmadas nas conferências subsequentes (Declaração de Adelaide, 1988; Declaração de Sundsvall, 1991; Declaração de Jacarta, 1997; Rede de Megapaises para a Promoção da Saúde, 1998; Declaração do México, 2000; Carta de Bangkok, 2005; Conferência de Nairóbi, 2009) aspectos como: 1) políticas públicas saudáveis; 2) a criação de entornos saudáveis ou de ambientes de apoio à Promoção da Saúde; 3) o fortalecimento da ação comunitária; 4) o desenvolvimento de habilidades pessoais; e 5) a reorientação dos serviços de saúde, foram incluídos para reforçar a ideia de que promover saúde está sempre além dos cuidados à saúde e envolve ações intersetoriais.

Os princípios definidos na carta de Ottawa passaram a orientar políticas e ações de muitos profissionais insatisfeitos com as abordagens higienistas e normatizadoras da educação em saúde e da prevenção de doenças, abordagens que reduziam os estados de saúde apenas como uma consequência dos comportamentos individuais.

Diferentemente, nesse novo pensar, se conceitua o indivíduo como um ser 
integral, cujo bem-estar físico, mental, social e espiritual é constantemente afetado por fatores biogenéticos e também pelo ambiente físico, social, econômico, político e cultural em que está situado.

Desse modo, a OMS passou a caracterizar ações em promoção de saúde aquelas baseadas nos sete seguintes princípios: concepção holística, intersetorialidade, empoderamento, participação social, equidade, ações multiestratégicas e sustentabilidade (WHO, 1998).

Como definições, a concepção holística determina que as iniciativas de promoção fomentem a saúde física, mental, social e espiritual pautando-se numa concepção que não restrinja a saúde à ausência de doenças, mas que seja capaz de atuar sobre seus determinantes.

A intersetorialidade é compreendida como uma conexão de conhecimentos e experiências de diversas áreas desde o planejamento até a realização e avaliação dos projetos de promoção de saúde.

A participação social, destacada como objetivo primordial da promoção de saúde é compreendida como o envolvimento das pessoas envolvidas nos processos de levantamentos de demandas, tomada de decisões, implantação de ações e avaliações das mesmas.

O princípio de empoderamento, que seria um processo de capacitação dos indivíduos e comunidades a um maior controle sobre os fatores pessoais, socioeconômicos e ambientais que afetam a saúde, está profundamente relacionado à educação e ao conhecimento, pois dessa forma possibilita aos cidadãos a legitimação de espaços democráticos, ao se fazer o reconhecimento das necessidades, desenvolvimento e acompanhamento de políticas que partam dos problemas por eles identificados.

$\mathrm{O}$ princípio equidade, pautado pelo objetivo de garantir o acesso universal à saúde, "consiste em eliminar as diferenças desnecessárias, evitáveis e injustas que restringem as oportunidades para se atingir o direito de bem-estar" (BRASIL, 2001).

O princípio relacionado às ações multiestratégicas fomentam a utilização de vários métodos de diferentes setores, como o desenvolvimento de políticas públicas, mudanças organizacionais, o desenvolvimento comunitário, questões legislativas, educacionais e do âmbito da comunicação (SÍCOLI, 2003).

A sustentabilidade remete à possibilidade de continuidade das ações, programas e políticas vigentes de promoção de saúde, se sustentando logística e financeiramente.

Baseando-se nesses princípios e com o objetivo de promover discussões sobre o 
impacto dos Determinantes Sociais da Saúde (DSS) no estado de saúde das populações, a OMS criou a Comissão sobre Determinantes Sociais da Saúde em 2005. Um ano depois, o Brasil foi o primeiro país a criar, através de Decreto Presidencial, uma Comissão Nacional sobre Determinantes Sociais da Saúde (CNDSS) com um mandato de dois anos.

Dentre os modelos que inter-relacionam os níveis de determinantes sociais e a situação de saúde, o movimento do CNDSS adotou o modelo de Dahlgren e Whitehead (1991), que inclui os DSS dispostos em diferentes camadas, segundo seu nível de abrangência, desde uma camada mais próxima aos determinantes individuais até uma camada distal onde se situam os macro determinantes (CNDSS, 2008).

Figura 1. Modelo de determinação social da saúde proposto por Dahlgren e Whitehead (1991)

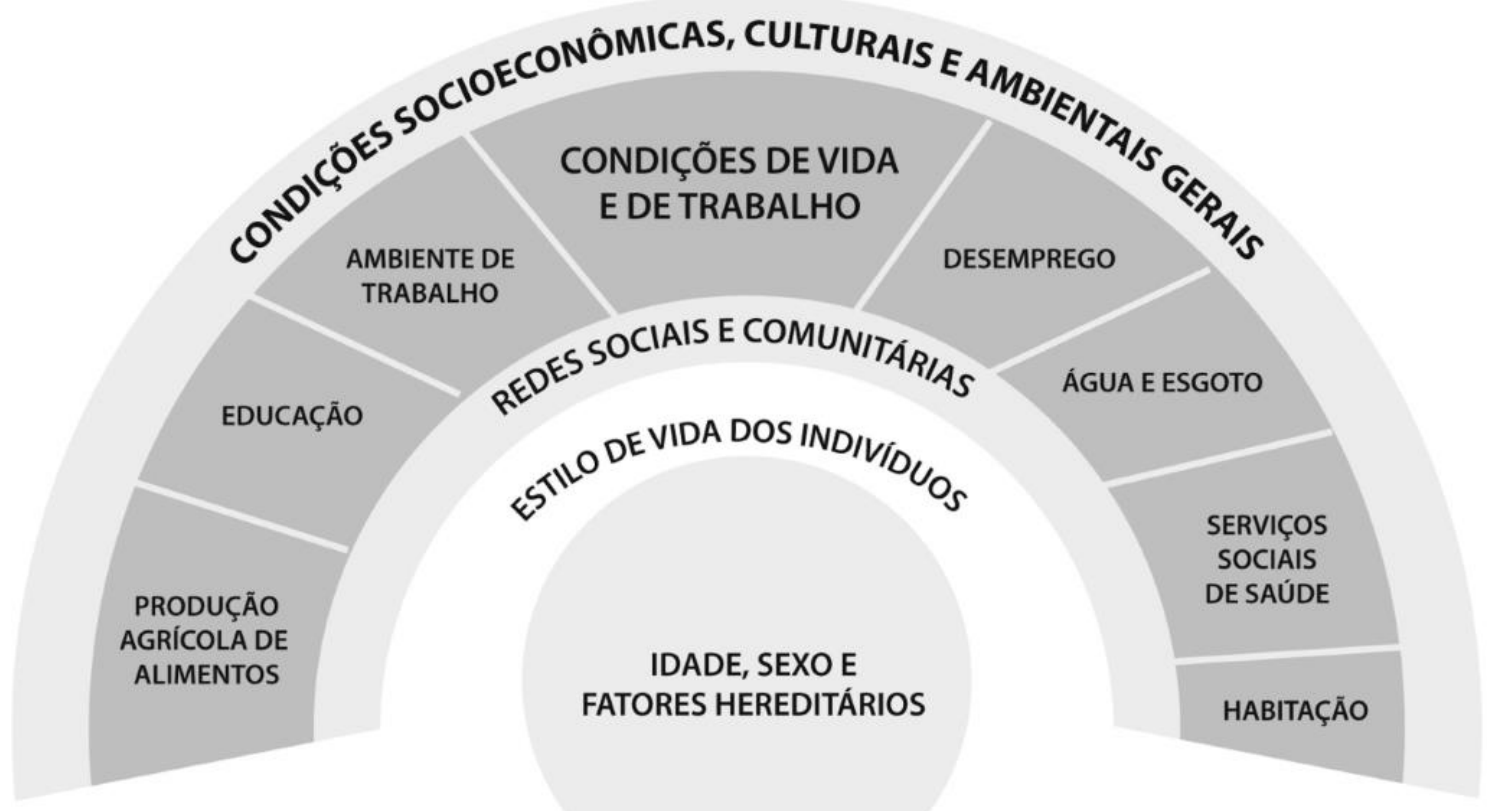

Fonte: CNDSS (2008)

Sob influência desse novo conceito e dos princípios norteadores da promoção da saúde, a discussão no Brasil que se iniciou em 1920 por Carlos Chagas (LIMA; PINTO, 2003) decorreu com a implantação do Sistema Único de Saúde e mais recentemente, dentro desse movimento da Promoção da Saúde, se concretizou com a criação da política nacional da saúde (Portaria n/ 687 MS/GM, de 30 de março de 2006) e redefinida na Portaria ${ }^{\circ}$ 2.446, de 11 DE NOVEMBRO de 2014 que tem como objetivo 
geral promover a equidade e a melhoria das condições e modos de viver, ampliando a potencialidade da saúde individual e da saúde coletiva, reduzindo vulnerabilidades e riscos à saúde decorrentes dos determinantes sociais, econômicos, políticos, culturais e ambientais, priorizando ações voltadas à: I - formação e educação permanente; II alimentação adequada e saudável; III - práticas corporais e atividades físicas; IV enfrentamento do uso do tabaco e seus derivados; V - enfrentamento do uso abusivo de álcool e outras drogas; VI - promoção da mobilidade segura; VII - promoção da cultura da paz e de direitos humanos; VIII - promoção do desenvolvimento sustentável, ações que compreendem promover, mobilizar e articular ações governamentais, não governamentais, incluindo o setor privado e a sociedade civil, nos diferentes cenários, como cidades, campo, floresta, águas, bairros, territórios, comunidades, habitações, escolas, igrejas, empresas e outros, permitindo a interação entre saúde, meio ambiente e desenvolvimento sustentável na produção social da saúde em articulação com os demais temas prioritários.

Ao pensar globalmente e agir localmente, a OMS levou esse movimento ao contexto escolar, a denominada Escola Promotora da Saúde (EPS), através do desenvolvimento de conhecimentos, habilidades e destrezas para o autocuidado da saúde e a prevenção de condutas de risco em todas as oportunidades educativas.

A promoção da saúde na escola vislumbra fomentar desde os anos iniciais de ensino, uma análise crítica e reflexiva sobre valores, condutas, condições sociais e estilos de vida, busca fortalecer tudo aquilo que contribui para a melhoria da saúde, da qualidade ambiental e do desenvolvimento humano; facilita a participação de todos os integrantes da comunidade educativa na tomada de decisões; colabora na promoção de relações socialmente igualitárias e reforça a solidariedade, o espírito de comunidade e os direitos humanos (OPS, 1996).

Pensar a promoção da saúde nas escolas através desses princípios possibilita extrapolar seus frutos além dos muros da escola, enriquecendo seu entorno, seu bairro, sua comunidade, sua cidade, e a tornar-se um espaço vital, gerador de estilos de vida saudáveis a toda sociedade.

Teoricamente as EPS são aquelas que contam com um edifício seguro e confortável, com agua potável, instalações sanitárias adequadas e uma atmosfera psicológica positiva para a aprendizagem; que possibilitam um desenvolvimento humano saudável; estimulam relações humanas construtivas e harmônicas e promovem atitudes positivas, conducentes à saúde (OPS, 1996). 


\subsection{PRIMEIROS PASSOS À UTOPIA DE SER UMA ESCOLA PROMOTORA DA SAÚDE}

Nada mais pertinente repensar minha escola como uma possível promotora de saúde, afinal, os Institutos Federais nasceram da necessidade de promover a justiça social, a equidade, o desenvolvimento sustentável com vistas à inclusão social, bem como a busca de soluções técnicas e novas tecnologias.

Em seus projetos pedagógicos, possuem como diretriz a educação como instrumento de transformação e enriquecimento do conhecimento, capaz de modificar a vida social e atribuir maior sentido e alcance ao conjunto da experiência humana (PACHECO, 2012).

Numa perspectiva de desenvolver políticas de inclusão produtiva e social, recebemos todos os anos, uma diversidade enorme de estudantes, estudantes que vieram de escolas privadas, públicas, com todas suas inerentes potencialidades e fragilidades, para iniciarmos juntos, um novo começo acadêmico.

Para que tenhamos êxito nessa diversidade, necessitamos de um constante repensar currículos, metodologias, projetos pedagógicos e formação humana dos servidores, legitimando assim um de nossos principais papéis, o de atender as demandas locais, e uma das estratégias utilizadas é a realização de diálogos com a comunidade escolar.

De forma empírica, percebo que os Institutos Federais acabam por se tornar referência em inúmeros quesitos aos municípios em que estão inseridos, não seria ousadia, portanto, almejar que sejamos também referência como promotores de saúde.

Pelicioni e Torres (1999) pontuam três tarefas a serem realizadas como ponto de partida para as escolas desenvolverem-se como EPS, são eles:

1. Desenvolver um plano escolar de educação e promoção da saúde que inclua:

- $\quad$ O desenho de um currículo especial flexível, de forma que os temas saúde e meio ambiente sejam ensinados transversalmente e respondam às necessidades específicas dos estudantes daquela localidade e faixa etária específica;

- A capacitação dos docentes e dos demais funcionários da escola para que se apropriem dos objetivos, conteúdos e métodos da Educação e da Promoção da Saúde, e da Educação Ambiental; 
- O desenvolvimento de um sistema de valores entre os estudantes e seus familiares, docentes, funcionários e comunidade onde a Instituição está inserida coerente com o conceito de Escola Promotora da Saúde, de forma a contribuir para a criação, a execução e manutenção de políticas públicas adequadas.

2. Estabelecer uma relação estreita com as famílias procurando:

- Consultas aos pais ou responsáveis sobre os assuntos de particular interesse e relevância, principalmente aqueles relacionados com as áreas de Saúde e Meio Ambiente;

- Informar sobre as finalidades e objetivos que a escola pretende atingir;

- Envolver os pais no processo de ensino-aprendizagem de seus filhos, utilizando materiais e estratégias cuidadosamente preparados, que possibilitem o diálogo, assim como a realização de atividades conjuntas.

3. Integrar a escola com a comunidade, de modo a:

- Incluir o pessoal dos serviços de saúde e de meio ambiente locais, no planejamento e na execução de programas escolares para a Promoção e Educação em Saúde e Educação Ambiental, e nas ações preventivas a serem desenvolvidas a partir da escola;

- Divulgar o trabalho desenvolvido na escola para a comunidade, contatar pessoas para a troca de experiências;

- Mobilizar recursos materiais e humanos que existam na comunidade para que a escola e seus entornos sejam saudáveis;

- Envolver o pessoal não docente, porteiros, merendeiras, agentes comunitários e lideranças locais nas atividades de capacitação, implantação e suporte à escola promotora de saúde.

Nesse primeiro momento, torno essa pesquisa um recorte da história de minha escola, um pontapé inicial para essa utopia. Ao dar voz aos meus estudantes, trago também as demandas da comunidade à nossa escola, e como consequência, possibilitamos levar a escola e seus frutos a essa comunidade.

Possibilitar e planejar esse momento sob o olhar e envolvimento dos alunos, me traz a hipótese de que em longo prazo, essas ações aqui firmadas possam ser mais sólidas e pertinentes a um estilo de vida ativo e saudável além do período de escolaridade.

Autores como Correia (1996) e Gandin (2001), através de resultados positivos de pesquisas com planejamento participativo, defendem a participação dos estudantes 
na construção do planejamento de ações educativas, descentralizando o poder, de modo que se sintam atuantes em todo o processo educacional, coerente com suas necessidades e que subsidie autonomia e liberdade de escolha na adoção de um estilo de vida saudável.

Qualquer conhecimento relativo à saúde, ao ensino de procedimentos e à formação de valores, será coerentemente incorporado se for fruto de debates sobre problemas reais vivenciados pelos estudantes na comunidade, ou, quando essas demandas levantadas forem solucionadas através de ações por eles sugeridas, permite-se que passem a se responsabilizar e a viver essa experiência de forma mais concreta e perene.

As EPS estão preocupadas com a formação de jovens com espírito crítico, capazes de refletir sobre os valores, a situação social e os modos de vida que favorecem a saúde e o desenvolvimento humano e que mantenham íntegro o meio ambiente (PELICIONE; TORRES 1999).

Nosso desafio se inicia, portanto, com o levantamento de dados para a compreensão da realidade, para que possamos futuramente transformá-la através de planos de estudo e ação de acordo com as necessidades que encontraremos e oportunidades e potencialidades que surgirão. 


\title{
5 MÉTODO
}

Para permitir que os objetivos propostos fossem alcançados, realizamos uma pesquisa qualitativa, descritiva, de caráter exploratório. Utilizamos como procedimento a Análise de Conteúdo, que tem como maior referência a pesquisadora Laurence Bardin, através de seu livro L'Analyse de Contenu (1977), publicado no Brasil com o título: Análise de Conteúdo.

A Análise de Conteúdo é um conjunto de técnicas de análise das comunicações, cujo fator comum é uma hermenêutica controlada, ou seja, a interpretação do sentido das palavras através de inferências (BARDIN, 2002).

De acordo com Oliveira (2008, p.571), entre as várias técnicas possíveis para a Análise de Conteúdo estão:

\begin{abstract}
Análise temática ou categorial, análise de avaliação ou representacional, análise de enunciação, análise da expressão, análise das relações ou associações, análise do discurso, análise léxica ou sintática, análise transversal ou longitudinal, análise do geral para o particular, análise do particular para o geral, analise segundo o tipo de relação mantida com o objeto estudado, análise dimensional e análise de dupla categorização em quadro de dupla entrada, dentre outras.
\end{abstract}

Nessa pesquisa buscamos analisar o significado que os adolescentes atribuem às estratégias de promoção da saúde e da atividade física no ambiente escolar e comunitário através da técnica de análise de conteúdo do tipo representacional, que entende a linguagem como representação e reflexo daquele que a utiliza (MINAYO, 2007).

\subsection{PROCEDIMENTOS}

A análise do material documental das aulas de educação física escolar foi realizada durante as aulas do período de agosto a dezembro de 2016, no curso de educação profissional técnica de nível médio em eletromecânica, modalidade presencial, com duração de 4 anos e turno de oferta integral.

Conforme a lei $\mathrm{n}^{\mathrm{o}} 10.793$, de $1^{\mathrm{o}}$ de dezembro de 2003, o projeto pedagógico do curso prevê a educação física, componente curricular obrigatório em 3 dos seus 4 anos; assim, no ano letivo de 2016, duas turmas, uma do $2^{\circ}$ e a outra do $3^{\circ}$ ano, estavam matriculadas nesse componente curricular, compondo portanto, a amostra de 65 estudantes, 18 meninas e 47 meninos. 
A intenção inicial era realizar um diagnóstico sobre possíveis estratégias para se promover saúde e atividade física no ambiente escolar e comunitário, e para isso um questionário foi pensado para que as descrevessem.

Ao desenvolvê-lo, levantou-se a dúvida sobre descrever ou não em seu cabeçalho os conceitos de ambiente escolar e comunidade, antecipando a possibilidade de confusões e sobreposições de interpretações.

Para isso, foi estipulada a necessidade de um projeto piloto que será descrito mais abaixo, onde não se faria a explicação dos conceitos presentes nas questões, para averiguarmos a possibilidade dessas ocorrências e aprimorar o questionário caso houvesse necessidade.

Após o projeto piloto, o questionário foi aplicado com os estudantes das duas turmas, em seguida foram elaborados os temas, e assim, o desenvolvimento das discussões.

\subsection{A ANÁLISE DE CONTEÚDO}

Para o desenvolvimento da Análise de Conteúdo nos baseamos nas orientações de Bardin, ao seguir as três etapas: pré-análise, exploração do material, tratamento dos resultados (inferência e a interpretação) (BARDIN, 2002).

Na pré-análise realizamos, um projeto piloto com a aplicação de um questionário sem identificação, para 4 estudantes, 3 meninas e um menino, escolhidos aleatoriamente; aconteceu na sala de aula em que ocorriam as aulas teóricas de educação física. Os estudantes participantes do projeto piloto responderam duas vezes, nesse momento, e na coleta oficial.

O questionário foi composto das seguintes questões:

1. O que deve ser realizado para promover a saúde de adolescentes no ambiente escolar?

2. O que deve ser realizado para promover a atividade física de adolescentes no ambiente escolar?

3. O que deve ser realizado para promover a saúde de adolescentes na sua comunidade? 
4. O que deve ser realizado para promover a atividade física de adolescentes na sua comunidade?

A aplicação dos questionários no projeto piloto durou cerca de 20 minutos e uma das estudantes perguntou se poderia condensar as quatro respostas em duas, visto que acreditava que as ações em atividade física e saúde deveriam ser as mesmas tanto no ambiente escolar como em sua comunidade, foi explicado que deveriam ser separadas visto que cada um dos espaços tinha suas particularidades.

Mediante o bom entendimento e facilidade de aplicação das questões e conceitos do projeto piloto, levando em consideração a dúvida e a sobreposição dos conceitos apresentada pela estudante, previamente imaginada em sua elaboração, avançamos para a segunda etapa, a aplicação com as duas turmas, porém com a descrição no cabeçalho e a leitura dos conceitos chave: ambiente escolar e comunidade presentes no questionário (ANEXO I).

O preenchimento em cada uma das duas turmas durou 25 minutos em média e não foi apresentada nenhuma dúvida de interpretação dos conceitos e questões pelos estudantes.

Seguindo essa etapa, realizei a leitura de cada um dos questionários preenchidos, e através de suas transcrições, separei as respostas de cada uma das quatro perguntas em arquivos individuais, onde obtive a exposição de todas as 65 respostas de cada uma delas, que também foram separadas por gênero.

$\mathrm{Na}$ exploração do material, foi realizado um levantamento das respostas dos estudantes; essa leitura e subsequente análise de conteúdo foram responsáveis pela definição dos temas que seriam discutidos em grupo. Foram escolhidos os temas que predominaram nas respostas mediante a frequência com que apareciam.

Com a leitura de suas respostas, estabelecemos algumas interpretações iniciais que delinearam a definição dos temas que seriam discutidos em grupo posteriormente.

\section{Promoção de atividades físicas na Escola e na Comunidade:}

- Levantamento e debate dos locais para a realização de atividades físicas na escola e na comunidade (4 aulas);

- Levantamento e debate das dificuldades em se realizar atividades físicas nos locais apresentados (4 aulas). 


\section{Promoção de atividades físicas na Escola e na Comunidade:}

- Levantamento dos estabelecimentos para refeições próximos à escola (4 aulas);

- Levantamento da necessidade de quais conhecimentos relacionados à saúde e de que maneira deveriam ser desenvolvidos na escola e na comunidade (4 aulas).

As discussões em grupo sobre os temas: "atividade física na escola e na comunidade" e "saúde na escola e na comunidade", foram planejados para acontecer em quatro encontros ( 8 aulas) para cada um deles e 2 aulas para fechamento da pesquisa, em um total de 10 aulas para cada turma.

Durante as aulas me orientei por um roteiro disposto no meu plano de aula, em que foi estimado o tempo destinado à chamada, o tempo para que se adequasse em suas carteiras, uma sequência estimada de tempo para as discussões dos temas e o tempo para a discussão final e encerramento da aula.

Incialmente a ideia de aplicar um questionário semiestruturado coletivamente me pareceu complexa, mas foi suavizada pelo pensamento de que as questões poderiam ser flexíveis mediante o andamento das discussões dos estudantes, em um ambiente em que me sentia segura por ter tido vivências positivas relacionadas a outras discussões tanto como professora, como coordenadora do curso.

De uma maneira geral, as aulas contaram com a seguinte estrutura: eu escrevia os tópicos a serem discutidos, acompanhados de suas explicações orais e no quadro; em alguns momentos foi pedido que os estudantes respondessem ou refletissem sobre algumas questões, eu os orientava a anotar essas respostas e reflexões individualmente em seus cadernos para posteriormente serem compartilhados em discussões coletivas.

Esses encontros foram moderados numa constante tentativa de tornar aquele momento encorajador aos estudantes para exporem suas ideias, sentimentos e significados; era frequente a fala que tais atividades não eram avaliativas, nem passíveis de julgamentos, mas sim parte de um planejamento coletivo visto a dificuldade anteriormente debatida em outras aulas em adotar um estilo de vida ativo e saudável nos espaços escolares e na comunidade.

Procurei manter uma sequência dos tópicos, do tempo disponível e propiciar um gerenciamento democrático da fala de cada um dos estudantes, no entanto em muitos 
momentos os próprios estudantes relacionavam suas explanações com as dos colegas, concordando, discordando e incitando as respostas de outros colegas e de novos temas.

Incialmente pensei em usar um gravador de áudio, mas pensei que se descaracterizaria das nossas rotinas de aulas, e que talvez esse instrumento os deixasse constrangidos ou fomentasse comportamentos que os tirariam de sua naturalidade. Escolhi levar o meu caderno rotineiro de anotações, transformando-o em diário de pesquisa.

Assim, como forma de registro e numa tentativa constante de interpretação, eu anotava em tópicos e em palavras chave a verbalização das respostas à medida que aconteciam. Estipulei que minha tarefa seria a de lançar os temas, ouvi-los, anotar suas respostas e aferir, através de seus sentimentos naquele momento, seus valores, sentimentos e comportamentos. Procurei interrompê-los muito pouco, a não ser que realmente não tivesse escutado algo.

Dando sequência às minhas anotações, ao término da aula, sem a presença dos estudantes e em um ambiente mais calmo, eu copiava o que havia escrito no quadro, acrescentava algumas lembranças e pontos que eu considerava marcantes e escrevia minhas interpretações iniciais de suas falas e do encontro como um todo. Essas lembranças e interpretações continuavam mesmo depois desse momento, eu lembrava detalhes, de rostos, e continuava a complementar minhas anotações.

As aulas seguiram o seguinte roteiro:

$\underline{\text { Levantamento e debate dos locais para a realização de atividades físicas na escola e na }}$ comunidade (4 aulas)

No primeiro encontro, na primeira aula, foi realizada uma caminhada pelo campus para reconhecimento dos lugares que aconteciam as práticas físicas e a possibilidade de novos espaços.

$\mathrm{Na}$ segunda aula, em sala de aula, foi requisitado aos estudantes que fizessem um levantamento dos locais propícios às atividades físicas que conheciam em sua comunidade; eles responderam em seus cadernos e à medida que terminavam, eu lia e anotava no quadro; quando o lugar mencionado era repetido, o assinalava para que pudéssemos visualizar o local mais frequentemente mencionado. Esse levantamento e anotações duraram cerca de 30 minutos em ambas as turmas.

Sentados em um grande círculo, li todos os locais mencionados, e lancei a 
pergunta: “O que pode ser realizado nesses locais?” E seguiu-se com as respostas dos estudantes, durante cerca de 40 minutos na turma 1 e 50 na turma 2.

Ao fim dessa aula, realizei um sorteio, onde grupos de 4 estudantes seriam responsáveis por visitar um dos locais mencionados, com a tarefa de mostrar fotos do local e contar quais foram as suas impressões na próxima aula que aconteceria em uma semana.

Nas duas aulas que se seguiram, cada grupo foi à frente da sala de aula contar sobre a visita que fizeram nos locais, com a projeção das fotos que tiraram.

$\underline{\text { Levantamento e debate das dificuldades em se realizar atividades físicas nos locais }}$ apresentados (4 aulas)

Ao retomar as aulas passadas, onde havíamos feito o levantamento dos locais, vimos à exposição das fotos e conversas sobre as características e possibilidades dos locais, foram lançadas duas perguntas, sequencialmente e com posterior discussão:

1. Vocês frequentam esses lugares?

2. Por que frequentam? Por que não frequentam?

$\underline{\text { Levantamento dos estabelecimentos para refeições próximos à escola (4 aulas) }}$

Nas duas aulas iniciais desse tópico foram realizadas três perguntas, sequencialmente e com tempos para as respostas entre elas:

1. O que vocês comem no intervalo das aulas e no almoço entre os turnos?

2. Vocês trazem lanches de casa?

3. Por que comem o que comem e onde comem?

Ao fim dessa aula, foi realizado um sorteio, onde os mesmos grupos de 4 estudantes do tópico anterior seriam responsáveis por fotografar os locais que vendiam e serviam lanches e refeições num raio de aproximadamente 1 quilometro, com a tarefa de mostrar fotos do local e contar o que esses estabelecimentos vendiam e serviam, na próxima aula que aconteceria em uma semana.

Nas duas aulas que se seguiram, cada grupo foi à frente da sala de aula mostrar 
as fotos dos estabelecimentos alimentares, e contaram o que era vendido e servido nos mesmos.

Após essa projeção, foram lançadas duas perguntas, sequencialmente e com posterior discussão:

1. Dos estabelecimentos escolhidos por vocês, é possível comprar e fazer lanches e refeições saudáveis?

2. Vocês os consomem? Por quê?

$\underline{\text { Levantamento da necessidade de quais conhecimentos relacionados à saúde e de que }}$ $\underline{\text { maneira deveriam ser desenvolvidos na escola e na comunidade (4 aulas) }}$

Nas duas aulas iniciais desse tópico foram realizadas três perguntas, sequencialmente e respectivamente:

1. Vocês se interessam por conteúdos relacionados à saúde?

2. De que forma os conhecimentos sobre saúde chegam até vocês?

3. Existe uma forma mais interessante desses conhecimentos chegarem até vocês?

$\underline{\text { Aula encerramento da pesquisa - no ano letivo seguinte }}$

A aula de encerramento da pesquisa ocorreu no início do ano letivo de 2017 com as duas turmas. Tal fato ocorreu, pois, nas duas últimas semanas de 2016 aconteceram algumas reuniões para os coletivos pedagógicos e os horários de aulas foram alterados. Dessa forma, decidi iniciar o ano letivo de 2017 com o diálogo de retomada para que as ações sugeridas e previstas nas discussões anteriores pudessem se iniciar, ou seja, um início para colocar em prática as sugestões apontadas pelo coletivo de estudantes sobre como a atividade física e a saúde poderiam acontecer na escola e na comunidade.

O tratamento dos resultados foi desenvolvido através de inferências e interpretações; segundo Houaiss, inferir é: concluir pelo raciocínio, a partir de fatos, indícios; deduzir.

A leitura dos questionários e da comunicação verbal e não verbal dos estudantes não apenas descreveram suas ideias, como também me oportunizou atingir níveis de 
compreensão sobre de que maneira acreditam que a promoção da saúde e da atividade física devam ser desenvolvidas na sua comunidade e escola.

\section{RESULTADOS}

\subsection{PROMOÇÃO DE ATIVIDADES FÍSICA NA ESCOLA E NA COMUNIDADE}

A maioria dos meninos e meninas conceituou atividade física (Quadro 1 e 2) associando-a com a ideia de esforço, de gasto calórico e atividades diversas como exercícios físicos, esportes e atividades cotidianas. As palavras "exercícios", "esportes" e "movimentos" foram encontrados em um número equivalente de ocorrências. No entanto, as meninas inclinaram-se a estender seus conceitos associandoos a aspectos biológicos da saúde como "sono", "peso”, "sedentarismo”, “calorias”, “tonificação".

Com a leitura dos questionários, notei algumas reivindicações importantes como espaços às práticas de atividades físicas e esportes na escola, com uso frequente de palavras como "locais", "ambiente”, "espaço" e "quadra”; mais atividades escolares com atividades físicas, tanto nas "aulas práticas" de educação física escolar, como em "projetos" e "esportes". Algo que me chamou a atenção é o frequente uso da palavra “incentivo”, incentivo às atividades físicas, projetos, esportes.

Quadro 1 - Definição do conceito de Atividade Física - Meninas

\begin{tabular}{|c|c|}
\hline \multicolumn{2}{|r|}{ Conceito de atividade física } \\
\hline 1 & $\begin{array}{l}\text { São ações que trabalham nossos músculos, é qualquer atividade relacionada ao } \\
\text { movimento. }\end{array}$ \\
\hline 2 & $\begin{array}{l}\text { É o conjunto de exercícios que tem como objetivo buscar uma boa qualidade de } \\
\text { vida }\end{array}$ \\
\hline 3 & $\begin{array}{l}\text { Que a atividade física é tudo para melhorar a sua vida, sua saúde e se cuidar com o } \\
\text { peso e melhorar o aumento de vida. }\end{array}$ \\
\hline 4 & $\begin{array}{l}\text { Movimentos que fazem bem para o corpo, proporcionando bem estar, como por } \\
\text { exemplo, dormir melhor. }\end{array}$ \\
\hline 5 & É tudo o que você faz no seu dia a dia que gaste energia. \\
\hline 6 & $\begin{array}{l}\text { Tem tudo a ver com a educação e saúde do nosso corpo. Prática de esportes, } \\
\text { academias e até uma caminhada é classificada como atividade física. }\end{array}$ \\
\hline 7 & é se movimentar fisicamente e praticar esporte. \\
\hline 8 & $\begin{array}{l}\text { Todo exercício continuo praticado, podendo ser rotineiro, mas sendo feito em um } \\
\text { determinado período de tempo. }\end{array}$ \\
\hline 9 & $\begin{array}{l}\text { Está relacionada a uma pratica de lazer, em que muitas das vezes o objetivo é a } \\
\text { queima de calorias. }\end{array}$ \\
\hline 10 & É quando você possui uma rotina e \\
\hline
\end{tabular}




\begin{tabular}{|c|l|}
\hline 11 & $\begin{array}{l}\text { São práticas que desenvolvem o corpo e melhoram a qualidade de vida se feito } \\
\text { rotineiramente. }\end{array}$ \\
\hline 12 & $\begin{array}{l}\text { Exercício para o corpo se movimentar, para não ficar parado e se entrevar. Não só } \\
\text { perder calorias, mas também para a tonificação e também diversão. }\end{array}$ \\
\hline 13 & $\begin{array}{l}\text { Praticas não necessariamente esportivas que contribuem para um condicionamento } \\
\text { mais correto do corpo humano; }\end{array}$ \\
\hline 14 & Algo que faz você se movimentar, aquilo que faz você sentir que o stress diminuiu. \\
\hline 15 & $\begin{array}{l}\text { Atividade física é algo que faz a vida ser mais saudável, é uma das coisas mais } \\
\text { importantes para o bem estar. }\end{array}$ \\
\hline 16 & $\begin{array}{l}\text { É todo exercício corporal que fazemos nem que seja uma caminhada ou coisa do } \\
\text { tipo, não precisa necessariamente ir para a academia, basta ter força de vontade. }\end{array}$ \\
\hline 17 & $\begin{array}{l}\text { Movimentos em que tenha gasto de calórico e enérgico com uma certa } \\
\text { intencionalidade. }\end{array}$ \\
\hline 18 & Qualquer movimento que fuja do sedentarismo. \\
\hline
\end{tabular}

Quadro 2 - Definição do conceito de Atividade Física - Meninos

\begin{tabular}{|l|l|}
\hline \multicolumn{2}{|c|}{ Conceito de Atividade Física } \\
\hline 1 & Se exercitar, praticar um esporte. \\
\hline 2 & É praticar esporte para se manter saudável sem problemas de saúde. \\
\hline 3 & $\begin{array}{l}\text { A realização de exercícios físicos acompanhados ou não por um profissional da } \\
\text { área. }\end{array}$ \\
\hline 4 & É esporte, mas pode ser também algo para manter o físico. \\
\hline 5 & É qualquer coisa que você faça que exija movimento. \\
\hline 6 & É praticar esportes como corridas, futebol, basquete, academia, entre outros. \\
\hline 7 & $\begin{array}{l}\text { É quando nós fazemos exercícios físicos que podem estar relacionados à diversão, } \\
\text { compromissos ou relação esportiva. }\end{array}$ \\
\hline 8 & Praticar algo que envolva o movimento, força, técnica, prática, e disciplina técnica. \\
\hline 9 & Esforço físico praticado em um esporte. \\
\hline 10 & Atividades que exijam esforço corporal. \\
\hline 11 & Fazer alguma coisa que exige esforço. \\
\hline 12 & $\begin{array}{l}\text { Podem ser compreendidas como esportes, mas também como lazer e servem para } \\
\text { você passar o tempo, se divertir, como também para ter uma vida saudável. }\end{array}$ \\
\hline 13 & Praticar exercícios para não ficar sedentário. \\
\hline 14 & $\begin{array}{l}\text { Qualquer movimento produzido pelo seu corpo voluntariamente. Hoje em dia a } \\
\text { atividade física é considerada atividade física quando você está fazendo } \\
\text { movimentos voluntários físicos, além de ações de andar para um determinado lugar } \\
\text { obrigatoriamente. }\end{array}$ \\
\hline 15 & Praticas para condicionamento físico. \\
\hline 16 & Pratica de esportes. \\
\hline 17 & $\begin{array}{l}\text { Atividades que movimentem o corpo, que nos deixem ativos, impedindo o } \\
\text { sedentarismo. }\end{array}$ \\
\hline 18 & Tudo o que faz você se movimentar. \\
\hline 19 & $\begin{array}{l}\text { Toda atividade que faz uma pessoa gastar energia, calorias e que deixa a pessoa } \\
\text { fisicamente preparada e ativa. }\end{array}$ \\
\hline 20 & Fazer exercícios. \\
\hline 21 & Toda atividade que exija movimento e um certo esforço. \\
\hline 22 & $\begin{array}{l}\text { Prática de esportes ou atividades que gastam energia "desnecessariamente" (pois é } \\
\text { uma energia que não seria utilizada se uma pessoa não fizesse caminhada, por }\end{array}$ \\
\hline
\end{tabular}




\begin{tabular}{|c|c|}
\hline & exemplo). \\
\hline 23 & É você praticar exercícios e esportes. \\
\hline 24 & $\begin{array}{l}\text { Pode ser uma rotina ou não, ela traz aprimoramentos físicos, estéticos, e qualidade } \\
\text { de vida. }\end{array}$ \\
\hline 25 & Praticar esportes em uma quadra. \\
\hline 26 & Corrida, bicicleta, futebol, ginastica, etc. \\
\hline 27 & $\begin{array}{l}\text { Atividades físicas têm que ser praticadas diariamente, pois para o corpo é muito } \\
\text { importante, não pela estética, mas pela saúde. }\end{array}$ \\
\hline 28 & Tudo aquilo que envolve uma atividade, um exercício, a prática de um esporte. \\
\hline 29 & Qualquer atividade e ações que geram um esforço físico. \\
\hline 30 & $\begin{array}{l}\text { É uma forma de se manter saudável, melhorar o corpo e a mente, interagir com } \\
\text { pessoas, é praticar algum esporte. }\end{array}$ \\
\hline 31 & $\begin{array}{l}\text { Atividades individuais ou em grupos que façam com que você se mexa, trabalhe } \\
\text { coordenação motora e que se canse. }\end{array}$ \\
\hline 32 & $\begin{array}{l}\text { Seria um exercício físico que você faz para se sentir bem, exemplo, jogar bola, } \\
\text { andar de bicicleta. }\end{array}$ \\
\hline 33 & $\begin{array}{l}\text { Aquilo que é benéfico à saúde, práticas esportivas em geral que possam trazer uma } \\
\text { boa saúde para a pessoa. }\end{array}$ \\
\hline 34 & Forma de estimulo à musculatura do corpo. \\
\hline 35 & $\begin{array}{l}\text { São práticas que fazem o corpo ter um gasto calórico e acabam por dar um bem } \\
\text { estar pessoal. }\end{array}$ \\
\hline 36 & $\begin{array}{l}\text { É simplesmente gastar energia, gastar o que você consumiu, não vejo como algo } \\
\text { necessariamente prazeroso como algumas pessoas, talvez por eu quase não praticar. }\end{array}$ \\
\hline 37 & $\begin{array}{l}\text { É você se exercitar, se movimentar. Deixar de lado aquela vida sedentária na frente } \\
\text { da tv ou do computador e ir fazer uma caminhada, andar de bicicleta no parque, } \\
\text { praticar esportes, em resumo, não ficar parado. }\end{array}$ \\
\hline 38 & Atividades que desenvolvam o físico corporal \\
\hline 39 & É um ato onde você se movimenta e gera prazer para si. \\
\hline 40 & É uma maneira de ter saúde e lazer, pois muita gente gosta de vôlei, futebol, etc. \\
\hline 41 & Tudo aquilo que nos faz gastar energia, é algo que nos faz muito bem. \\
\hline 42 & É a ação de se movimentar fisicamente e praticar esportes. \\
\hline 43 & $\begin{array}{l}\text { Exercícios que fazem bem para a saúde, que consequentemente pode ganhar } \\
\text { músculos ou perder gordura. }\end{array}$ \\
\hline 44 & Pratica de algo que exercite seus músculos. \\
\hline 45 & Algo que exija um esforço do seu corpo além do rotineiro. \\
\hline 46 & Ir à academia, ter uma rotina e uma alimentação adequada. \\
\hline 47 & Qualquer esforço que promova grande gasto de energia. \\
\hline 48 & $\begin{array}{l}\text { Exercícios em geral, praticar esportes, atividades intensas, a minha preferida é } \\
\text { jogar futebol. }\end{array}$ \\
\hline
\end{tabular}

Débora Navarro Rocha, 2017

Nas aulas que se seguiram às respostas dos questionários, foram realizadas as caminhadas pelo campus, com o objetivo de reconhecer os lugares da escola que aconteciam as práticas físicas e o levantamento de novas possibilidades de espaços (Quadros 3 e 4). 
Quadro 3 - Promoção da Atividade Física na Escola - Meninas

\begin{tabular}{|c|c|}
\hline & Promoção da Atividade Física na Escola \\
\hline 1 & Local adequado, incentivo, mais aulas práticas de educação física. \\
\hline 2 & $\begin{array}{l}\text { Disponibilizar aos alunos um espaço adequado e materiais para que seja possível } \\
\text { realizar atividades variadas com os alunos. }\end{array}$ \\
\hline 3 & $\begin{array}{l}\text { Ter quadras nas escolas, material de exercício e programas para nós ficarmos livres } \\
\text { para fazer qualquer esporte na escola. }\end{array}$ \\
\hline 4 & $\begin{array}{l}\text { Momentos que praticamente "obrigue" o adolescente a começar a praticar, pois } \\
\text { assim irá gostar com o tempo, pois se for livre muitos vão ficar no celular sem } \\
\text { praticar nada. }\end{array}$ \\
\hline 5 & Incentivar dando ideias de atividades que se encaixe no dia a dia. \\
\hline 6 & $\begin{array}{l}\text { Incentivando os alunos a praticarem esportes nos períodos de aulas e fazendo } \\
\text { projetos para a prática dos mesmos. }\end{array}$ \\
\hline 7 & Ter lugares gratuitos para a prática de esporte. \\
\hline 8 & $\begin{array}{l}\text { Podem ser realizadas aulas de exercícios físicos, esportes, caminhadas e até mesmo } \\
\text { um momento para alongamentos, uma vez que ficamos sentados em sala por mais } \\
\text { ou menos } 5 \text { horas. }\end{array}$ \\
\hline 9 & Primeiramente deve-se possuir uma boa estrutura e depois a prática. \\
\hline 10 & $\begin{array}{l}\text { Um ambiente adequado, espaços, materiais, e professores responsáveis por } \\
\text { compartilhar e aplicar todos os seus conhecimentos. }\end{array}$ \\
\hline 11 & Espaços seguros e completos, professores para ensinar as técnicas, jogos escolares. \\
\hline 12 & Adequação de espaços no colégio. \\
\hline 13 & $\begin{array}{l}\text { Tudo começa em casa, principalmente com exemplos, é um problema, impregnado } \\
\text { na nossa sociedade e dificilmente os pais mudam, começar pelas crianças, porque } \\
\text { ela vai crescer de acordo com o ensinado. }\end{array}$ \\
\hline 14 & Aulas mais práticas, não ficar 4 horas ou mais parados. \\
\hline 15 & $\begin{array}{l}\text { Para a prática de mais atividades físicas no ambiente escolar, primeiramente ter um } \\
\text { bom espaço para a prática e segundo fazer projetos esportivos. }\end{array}$ \\
\hline 16 & Organizando algo cativante, divertido para incentivar os alunos mais preguiçosos. \\
\hline 17 & $\begin{array}{l}\text { Espaço para a prática esportiva adequado, incentivo à prática de alguma } \\
\text { modalidade, e materiais em bom estado para a utilização. }\end{array}$ \\
\hline 18 & Disponibilização de quadras, bolas, colchonetes e afins para os alunos. \\
\hline
\end{tabular}

Débora Navarro Rocha, 2017

Quadro 4 - Promoção da Atividade Física na Escola - Meninos

\begin{tabular}{|l|l|}
\hline \multicolumn{2}{|c|}{ Promoção da Atividade Física na Escola } \\
\hline 1 & Ter um local adequado para fazer atividades físicas, por exemplo quadra! \\
\hline 2 & $\begin{array}{l}\text { Prática de esportes na aula de Ed. Física de manhã, e uma atividade diferenciada no } \\
\text { Parque Cambuí, um futebol de campo, tênis, vôlei de areia. }\end{array}$ \\
\hline 3 & $\begin{array}{l}\text { A prática de esportes variados nas aulas de educação física ou até mesmo } \\
\text { caminhadas. }\end{array}$ \\
\hline 4 & $\begin{array}{l}\text { A escola deve fazer projetos com alguns esportes, assim os jovens irão praticar } \\
\text { atividades físicas. }\end{array}$ \\
\hline 5 & $\begin{array}{l}\text { Projetos que estimulem os exercícios de uma forma divertida como por exemplo } \\
\text { escolinha de futsal. }\end{array}$ \\
\hline 6 & Mais aulas com passeios, trabalhos práticos ao ar livre etc. \\
\hline 7 & $\begin{array}{l}\text { Mais aulas de educação física e alimentação na cantina mais saudável e mais } \\
\text { projetos extraclasse. }\end{array}$ \\
\hline 8 & Pincipalmente promover incentivos. \\
\hline
\end{tabular}




\begin{tabular}{|c|c|}
\hline 9 & Organizar um dia e um período para realização das atividades. \\
\hline 10 & Ter uma quadra apropriada e programas de esportes. \\
\hline 11 & Ter melhores condições e também levar os adolescentes para lugares. \\
\hline 12 & $\begin{array}{l}\text { Poderiam ser criados grupos esportivos em horários diferenciados, abordando todos } \\
\text { os grupos de alunos. }\end{array}$ \\
\hline 13 & Mais aulas ao ar livre com praticas regulares. \\
\hline 14 & Uma quadra descente para a pratica de esportes ser possível. \\
\hline 15 & Incentivar a pratica de esportes, ter uma quadra, levar e promover mais torneios. \\
\hline 16 & Praticar mais esportes. \\
\hline 17 & Incentivar a pratica de esportes através de jogos escolares, gincanas, treinos, etc. \\
\hline 18 & Apoiar os esportes e ter local para praticar. \\
\hline 19 & Um lugar para ser usado como uma quadra ou um lugar para fazer exercícios. \\
\hline 20 & $\begin{array}{l}\text { Ter uma boa quadra de esportes, com diversas modalidades, para praticarem e } \\
\text { liberar os alunos para fazer os esportes. }\end{array}$ \\
\hline 21 & Obriga-los a participar das aulas de edf. \\
\hline 22 & Ter um ambiente adequado e o incentivo. \\
\hline 23 & $\begin{array}{l}\text { Os professores incentivarem os alunos, manter quadras e outros materiais } \\
\text { esportivos em condições adequadas. }\end{array}$ \\
\hline 24 & $\begin{array}{l}\text { Aulas práticas, projetos onde possa entender e praticar o assunto, e materiais de } \\
\text { esportes corretos. }\end{array}$ \\
\hline 25 & Quadras, mais aulas de educação física. \\
\hline 26 & Aulas práticas. \\
\hline 27 & $\begin{array}{l}\text { Incentivo à pratica de esporte, boa infraestrutura e profissionais disponíveis para } \\
\text { ajudar os alunos. }\end{array}$ \\
\hline 28 & O incentivo através da pratica de esportes que animam seus participantes. \\
\hline 29 & Igual a 3 \\
\hline 30 & $\begin{array}{l}\text { ter um espaço amplo para a realização de atividades com segurança e também um } \\
\text { bom incentivo por parte dos professores. }\end{array}$ \\
\hline 31 & Realizar inter salas, fazer projetos que incentivem o esporte, construir uma quadra. \\
\hline 32 & $\begin{array}{l}\text { Mais acesso para esportes e atividades no contraturno, para que se possa ter uma } \\
\text { rotina e manter uma qualidade boa de atividade física frequente. }\end{array}$ \\
\hline 33 & Uma quadra de esportes apropriadas para os esportes. \\
\hline 34 & $\begin{array}{l}\text { Espaços apropriados, orientações, divulgações, motivação, porque é muito mais } \\
\text { cômodo você fica em casa vendo televisão, mexendo no computador, fazendo } \\
\text { qualquer outra coisa, mas no conforto de sua casa. Então falta essa chamada de ir } \\
\text { atrás das pessoas. }\end{array}$ \\
\hline 35 & $\begin{array}{l}\text { Incentivo por parte da escola, com treinos, ensinando praticas de novos esportes, } \\
\text { aulas práticas, material de prática, espaço, etc. }\end{array}$ \\
\hline 36 & Aulas práticas. \\
\hline 37 & $\begin{array}{l}\text { Ser disponibilizados materiais de qualidade para a prática das atividades, aulas que } \\
\text { mostrem como fazer uma boa prática. }\end{array}$ \\
\hline 38 & $\begin{array}{l}\text { Ter um ginásio com muitas modalidades de esportes pois assim os alunos podem } \\
\text { criar o gosto por outros esportes. }\end{array}$ \\
\hline 39 & Projetos e aulas práticas de edf \\
\hline 40 & Mais estrutura para a prática de atividades físicas. \\
\hline 41 & O uso a mais de quadras de esportes, jogos que possam se movimentar, etc. \\
\hline 42 & Incentivos como um aumento na média, como nos EUA. \\
\hline 43 & $\begin{array}{l}\text { Se a professora não der nota por tarefa de exercícios físicos não farei exercícios } \\
\text { físicos, não tem nada que possa ser feito, a não ser se for obrigatório. }\end{array}$ \\
\hline
\end{tabular}




\begin{tabular}{|l|l|}
\hline 44 & Fornecer um espaço adequado aos alunos. \\
\hline 45 & $\begin{array}{l}\text { Organizar gincanas atividades que assim como estimulam as pessoas a praticar } \\
\text { atividades físicas, estimule também o aprendizado. }\end{array}$ \\
\hline 46 & As aulas de educação física contribuem muito para isso. \\
\hline 47 & Ter um local adequado para fazer atividades físicas. \\
\hline 48 & $\begin{array}{l}\text { Prática de esportes na aula de Ed. Física de manhã, e uma atividade diferenciada no } \\
\text { Parque Cambuí, um futebol de campo, tênis, vôlei de areia. }\end{array}$ \\
\hline
\end{tabular}

Débora Navarro Rocha, 2017

Essas caminhadas foram marcadas por duas sensações; a primeira de indignação com a falta de espaços, bem exemplificada quando os estudantes passaram no galpão que têm as quadras adaptadas, o tom da fala coletiva tinha certo desdém e zombaria quando apontavam os furos do teto, as poças d'água, os carros dos servidores estacionados proximamente. Foram muito marcantes frases como "temos muitos materiais parados", "as bolas de vôlei estragam rapidamente nesse chão", "olha o estado da mesa" "precisamos de espaços adequados" e as inúmeras menções e deboches sobre o "ginásio que nos prometeram".

Um momento bem interessante com a turma do $3^{\circ}$ ano foi quando passamos por um depósito abandonado onde desenvolvi anteriormente algumas aulas práticas de ginástica; os colchonetes utilizados ainda estavam lá, bem empoeirados e quase inutilizáveis, alguns se lembraram da "aula de yoga" e brincaram bastante comigo por realizá-la naquele lugar tão feio, associando "o estado em que estavam os colchonetes" com o "estado que as roupas deles ficavam". Em tom de brincadeira concordei que foi uma "péssima ideia".

Num dos momentos dessa caminhada, com a turma do $2^{\circ}$ ano, fomos ao bloco recém-construído, conhecido como bloco administrativo, onde no piso térreo passou a funcionar a nova biblioteca e no andar de cima, as salas dos professores, coordenações e setor administrativo. Um dos estudantes comentou que a biblioteca "era o melhor lugar da escola" justificando por ser o espaço mais novo, amplo e com um piso "menos duro", o bibliotecário nos recebeu nessa visita e ao ouvir esse comentário, lançou a ideia de dividirmos o espaço para as aulas de educação física; gostamos da ideia de uma maneira geral e se seguiram momentos de divagações sobre propostas da divisão dos espaços, horários e tipos de atividades físicas possíveis; o clima foi de animação e combinei que consultaria a direção.

A ideia de realizar as aulas de educação física na biblioteca se espalhou entre os estudantes de todas as turmas após essa aula e nos próximos dias que se seguiram, fui 
constantemente cobrada sobre o retorno com a direção, que gostou da ideia e se prontificou a planejarmos como aconteceriam no próximo ano letivo de 2017.

Nessas caminhadas, conversamos também sobre os projetos esportivos de vôlei, basquete e tênis de mesa que já estavam sendo desenvolvidos pelos estudantes; os estudantes entusiastas dos mesmos pediram para que eu permitisse que continuassem no próximo ano, mesmo nas condições que se encontrava o galpão; perguntei o que acontecia quando chovia ou escurecia, e me disseram que esses encontros estavam acontecendo com frequência também nos parques e quadras da cidade. Percebi que na realidade esses "projetos" acabaram por se tornar encontros para jogar essas modalidades e que contavam com o fato de ter alguns estudantes que organicamente foram eleitos os "responsáveis" pelos mesmos, o que tornava essa rotina mais organizada e frequente.

Nas aulas que se seguiram, os estudantes levantaram os locais propícios às atividades físicas que conheciam em sua comunidade, foram momentos que demonstraram bastante entusiasmo; notei que os espaços pontuados eram na sua grande maioria conhecidos por todos e aproveitei o fato de ser nova na cidade para perguntar onde e como eram, o que realizaram com muita satisfação; alguns inclusive me mostravam nos celulares os caminhos para chegar, comentavam que era "próximo da casa da senhora”, que dava para "ir a pé”, e quando percebi estava ocorrendo uma discussão e um grande relembrar dos espaços em que os estudantes, empoderados, por poder explicar aos colegas e principalmente a mim, quão próximos esses lugares eram de suas casas e o que já haviam feito neles, criaram-se também uma expectativa do que poderíamos fazer nesses espaços e propostas como "irmos em um fim de semana", "fazermos piqueniques", "caminhadas" e "trilhas".

De uma maneira geral, quando responderam no questionário "o que deve ser realizado para promover a atividade física de adolescentes na sua comunidade", (Quadros 5 e 6) a ideia que se se tem é que meninos e meninas pensam que suas comunidades podem promovê-la através da criação e manutenção de espaços para atividades físicas "ciclovias", "faixas de caminhada", "quadras esportivas", ressaltando a necessidade de "segurança".

Quadro 5 - Promoção da Atividade Física na Comunidade - Meninas Promoção da Atividade Física na Comunidade

1 Projetos de incentivo na comunidade, mais parques e outros meios de diversão. 


\begin{tabular}{|c|c|}
\hline 2 & mvestur em segurança nas praças e parques. \\
\hline 3 & $\begin{array}{l}\text { Ter quadra de futebol e equipamentos para todos se exercitarem e também para } \\
\text { melhorar a segurança ter guardas para que possamos ir a qualquer momento se } \\
\text { exercitar. }\end{array}$ \\
\hline 4 & $\begin{array}{l}\text { Incentivos, formas diferentes que chamem atenção, pois ultimamente todos estão } \\
\text { sedentários. }\end{array}$ \\
\hline 5 & $\begin{array}{l}\text { Abrir mais espaços para que se possa ser realizadas as atividades físicas e que } \\
\text { sejam espaços com segurança. }\end{array}$ \\
\hline 6 & $\begin{array}{l}\text { Criar programas de práticas de esportes ou atividades físicas em geral, como } \\
\text { basquete, ciclismo, ginasticas, jogos de vôlei, e tudo a ver com esportes. }\end{array}$ \\
\hline 7 & Mais espaços para irmos. \\
\hline 8 & $\begin{array}{l}\text { Pode ser realizados eventos como corridas, caminhadas, grupos de ciclismo, jogos } \\
\text { escolares, e construção/abertura de locais onde jovens possam se juntar } \\
\text { gratuitamente para realizar atividades culturais e esportivas. }\end{array}$ \\
\hline 9 & Melhoramento nas estruturas oferecidas pelo município. \\
\hline 10 & $\begin{array}{l}\text { O acesso, a oportunidade, assim como a educação de que atividade física é } \\
\text { necessária para a vida. }\end{array}$ \\
\hline 11 & $\begin{array}{l}\text { Aulas gratuitas de vôlei, basquete entre outros, disponibilizar mais espaços } \\
\text { coerentes, ex. vila olímpica. }\end{array}$ \\
\hline 12 & Investimentos em ambientes que abranjam o esporte para a sociedade. \\
\hline 13 & $\begin{array}{l}\text { Tudo começa em casa, principalmente com exemplos, é um problema, impregnado } \\
\text { na nossa sociedade e dificilmente os pais mudam, começar pelas crianças, porque } \\
\text { ela vai crescer de acordo com o ensinado. }\end{array}$ \\
\hline 14 & $\begin{array}{l}\text { Projetos onde façam com que os adolescentes se envolvam mais, trabalhem mais, } \\
\text { se movimentando, do que ficarem parados ou no celular, computador ou TV. }\end{array}$ \\
\hline 15 & $\begin{array}{l}\text { Ter mais formas de realizar atividades, investir em ciclovias, e de alguma forma } \\
\text { melhorar a segurança em locais que já têm alguma estrutura para realizar as } \\
\text { atividades físicas. }\end{array}$ \\
\hline 16 & $\begin{array}{l}\text { Demonstrando quanto faz bem uma atividade física regular e o quanto pode ser } \\
\text { divertido se exercitar com os amigos. }\end{array}$ \\
\hline 17 & Incentivo para as práticas esportivas do município e da família. \\
\hline 18 & $\begin{array}{l}\text { Academias gratuitas ou ao ar livre, iniciativa esportiva da prefeitura para com os } \\
\text { moradores, parques, etc. }\end{array}$ \\
\hline
\end{tabular}

Débora Navarro Rocha, 2017

Quadro 6 - Promoção da Atividade Física na Comunidade - Meninos

\begin{tabular}{|l|l|}
\hline \multicolumn{2}{|c|}{ Promoção da Atividade Física na Comunidade } \\
\hline 1 & Locais para se exercitar, como parques. \\
\hline 2 & Eventos no parque patrocinados pela prefeitura. \\
\hline 3 & Mutirões opcionais para realização de esporte, caminhadas e exercícios. \\
\hline 4 & Criar quadras e com isso projetos para treinar os jovens. \\
\hline 5 & $\begin{array}{l}\text { Aumentar o acesso das pessoas a locais propícios a atividades físicas, como por } \\
\text { exemplo a criação de novos parques e quadras de esporte. }\end{array}$ \\
\hline 6 & Mais quadras e lugares gratuitos para praticar esportes. \\
\hline 7 & Construção de parques e quadras para todos, e aulas de esportes de graça. \\
\hline 8 & A galera sair da rede social e passar a ter vida social. \\
\hline 9 & Construção de espaços para a prática de esportes. \\
\hline 10 & $\begin{array}{l}\text { Coisas básicas como quadra local, faixa de caminhada já nos estimulam a praticar } \\
\text { atividades, pois aí não tem separação de camadas sociais. }\end{array}$ \\
\hline
\end{tabular}




\begin{tabular}{|c|c|}
\hline 11 & $\begin{array}{l}\text { Deve mostrar que existem lugares que podem ajudar a praticar atividades físicas e } \\
\text { fazer os adolescentes sentirem vontade de deixar a tecnologia e ir para esses } \\
\text { lugares. }\end{array}$ \\
\hline 12 & Devem ser mais incentivados a praticar esportes. \\
\hline 13 & $\begin{array}{l}\text { O incentivo dos pais em tirar o filho de casa, para que não fique somente em frente } \\
\text { à TV. }\end{array}$ \\
\hline 14 & Praças e ambientes para exercícios e atividades físicas. \\
\hline 15 & Os pais têm que dar uma forçada para saírem de casa, manda um castigo e pronto. \\
\hline 16 & Mais esportes. \\
\hline 17 & $\begin{array}{l}\text { Melhor organização do espaço publico, como ciclovias, faixas para caminhadas, } \\
\text { ginásios, academias ao ar livre, etc. }\end{array}$ \\
\hline 18 & Apoiar a prática e mais locais para praticar. \\
\hline 19 & $\begin{array}{l}\text { Lugares específicos para o esporte, como escolas e lugares para andar de bike, } \\
\text { correr e caminhar. }\end{array}$ \\
\hline 20 & Ter lugares públicos para a prática de esportes, as crianças serem menos mimadas. \\
\hline 21 & $\begin{array}{l}\text { Seja criativo nas propagandas sobre as atividades físicas. Adolescentes não dão } \\
\text { atenção Às coisas, a menos que seja impossível percebê-las. }\end{array}$ \\
\hline 22 & Construção de quadras públicas e programas que apoiam o esporte. \\
\hline 23 & Manter os locais de esportes em condições adequadas, segurança. \\
\hline 24 & $\begin{array}{l}\text { Disponibilizar lugares específicos em cidades e procurar incentivar por meios de } \\
\text { comunicação. Também se pode organizar um grupo de pessoas para promover } \\
\text { essas atividades. }\end{array}$ \\
\hline 25 & Melhor infraestrutura na cidade. \\
\hline 26 & $\begin{array}{l}\text { As chamadas escolinhas de futebol, basquete, etc. e isso é uma forma de tirar os } \\
\text { adolescentes de possíveis enrascadas, pois lá estão praticando um esporte e } \\
\text { aprendendo o que é certo. }\end{array}$ \\
\hline 27 & $\begin{array}{l}\text { Na comunidade já é mais difícil, pois não são todos que querem praticar atividades } \\
\text { físicas diariamente. }\end{array}$ \\
\hline 28 & Mais lugares adequados à atividade física. \\
\hline 29 & $\begin{array}{l}\text { O incentivo com projetos que sejam de agrado de todos, por meio de práticas } \\
\text { esportivas. }\end{array}$ \\
\hline 30 & Mais espaços públicos. \\
\hline 31 & $\begin{array}{l}\text { Ter espaços para a realização destas atividades, espaços seguros e também ter uma } \\
\text { boa divulgação desses espaços e participação da comunidade. }\end{array}$ \\
\hline 32 & $\begin{array}{l}\text { Melhorar os horários disponíveis na vila olímpica, construir mais quadras, arrumar } \\
\text { e manter as que já temos para que possam voltar a ser usadas com a devida } \\
\text { frequência. }\end{array}$ \\
\hline 33 & Construir ginásios, realizar campeonatos. \\
\hline 34 & $\begin{array}{l}\text { Mais acesso gratuito a diferentes formas de atividade física não só nos esportes } \\
\text { como danças etc. }\end{array}$ \\
\hline 35 & Mais parques, academias e ginásios públicos. \\
\hline 36 & $\begin{array}{l}\text { Propaganda sobre os benefícios, investir em lugares nos quais se pode praticar } \\
\text { esportes. }\end{array}$ \\
\hline 37 & $\begin{array}{l}\text { Espaços, pois em alguns lugares, não só no meu bairro, não há um parque próximo, } \\
\text { uma calçada, é tudo meio limitado. }\end{array}$ \\
\hline 38 & $\begin{array}{l}\text { Considero que com o incentivo, e com os itens listados na pergunta anterior, não só } \\
\text { os adolescentes, mas toda a comunidade pode e deve praticar esportes. }\end{array}$ \\
\hline 39 & Centros esportivos. \\
\hline 40 & Locais onde se possa ser feita a atividade, em que esteja em boas condições e ser \\
\hline
\end{tabular}




\begin{tabular}{|l|l|}
\hline & promovidas mais torneios, campeonatos de diversas modalidades. \\
\hline 41 & Segurança nos campos, pistas e quadras. \\
\hline 42 & $\begin{array}{l}\text { Da mesma forma que é ensinada a historia, a matemática, deveria ser ensinado } \\
\text { como ser saudável. }\end{array}$ \\
\hline 43 & Mais estruturas na comunidade, assim, mais adolescentes praticarão esportes. \\
\hline 44 & Os mesmo programas de saúde, mas com atividades que se exercitam. \\
\hline 45 & Quadras esportivas. \\
\hline 46 & Ensinar a se exercitar e mostrar resultados. \\
\hline 47 & $\begin{array}{l}\text { Em todos os itens acho que deveria diminuir os conteúdos das ementas de } \\
\text { matemática, física, biologia e desenho mecânico e eletrotécnico. }\end{array}$ \\
\hline 48 & Incentivo de amigos, familiares. \\
\hline
\end{tabular}

Débora Navarro Rocha, 2017

Quando todos os locais estavam escritos no quadro os li e lancei a pergunta " $o$ que pode ser realizado nesses locais?".

Ao fim dessa aula, realizei um sorteio, onde grupos seriam responsáveis por visitar um dos locais mencionados. As duas aulas seguintes foram utilizadas para as apresentações das fotos; conclui a aula lendo as possibilidades que levantaram nas aulas passadas sobre os locais antes das visitas e levantei as seguintes questões, para que pensassem para responder nas próximas "Vocês frequentam esses lugares? Por que frequentam? Por que não frequentam?".

Nas duas aulas seguintes, retomei a atividade e refiz as perguntas, cerca de um terço dos estudantes responderam frequentar os locais. Em posse desse número baixo, passei a perguntar novamente, agora levantando as questões "por que frequentam? $e$ por que não frequentam" para cada um dos locais.

Projetei meu computador no multimídia e à medida que justificaram os motivos de frequentarem ou não cada um dos locais, sugeri que em conjunto desenvolvêssemos um quadro com os locais, suas possibilidades e os aspectos positivos e negativos.

Fiz um quadro separadamente com cada uma das turmas, e as respostas em muito foram similares, a união das respostas, portanto, formou o quadro que se segue.

Quadro 7 - Espaços locais, suas possibilidades, aspectos positivos e negativos.

\begin{tabular}{|l|c|c|c|}
\hline \multicolumn{4}{|c|}{ Espaços locais, suas possibilidades, aspectos positivos e negativos. } \\
\hline Locais & Possibilidades & Aspectos positivos & Aspectos negativos \\
\hline
\end{tabular}




\begin{tabular}{|c|c|c|c|}
\hline $\begin{array}{l}\text { Biblioteca } \\
\text { IFPR }\end{array}$ & $\begin{array}{l}\text { Ginásticas; } \\
\text { Circuitos; Danças; } \\
\text { Alongamentos; Ex. } \\
\text { funcionais; Aulas } \\
\text { teóricas; Aulas de } \\
\text { culinária. }\end{array}$ & $\begin{array}{c}\text { Tamanho; Piso; Sala } \\
\text { para materiais; } \\
\text { Bebedouro; Banheiros; } \\
\text { Privacidade. }\end{array}$ & $\begin{array}{l}\text { Não seria possível } \\
\text { realizar atividades } \\
\text { esportivas; Dividir } \\
\text { horário com a } \\
\text { biblioteca. }\end{array}$ \\
\hline Galpão IFPR & $\begin{array}{l}\text { Quadras adaptadas; } \\
\text { Modalidades } \\
\text { esportivas; Projetos } \\
\text { esportivos; Corridas. }\end{array}$ & Tamanho. & $\begin{array}{l}\text { Falta de iluminação; } \\
\text { Piso inadequado; } \\
\text { Distante do } \\
\text { bebedouro; } \\
\text { Estacionamento de } \\
\text { carros; Sujo; } \\
\text { Desmotivante; } \\
\text { Passagem para os dois } \\
\text { blocos. }\end{array}$ \\
\hline $\begin{array}{l}\text { Parque } \\
\text { Cambuí - } \\
\text { Newton } \\
\text { Puppi }\end{array}$ & $\begin{array}{c}\text { Caminhadas; } \\
\text { corridas; trilhas; } \\
\text { Pista de atletismo; } \\
\text { Ginástica; } \\
\text { Alongamento; } \\
\text { Exercícios na } \\
\text { academia ao ar livre; } \\
\text { Esportes. }\end{array}$ & $\begin{array}{l}\text { Longas trilhas de } \\
\text { caminhada; Food } \\
\text { trucks; Quadras } \\
\text { diversas; Beleza. }\end{array}$ & $\begin{array}{l}\text { Distante; Perigoso; } \\
\text { Pouca iluminação; } \\
\text { Não é possível ir } \\
\text { sozinho. }\end{array}$ \\
\hline $\begin{array}{l}\text { Parque da } \\
\text { Lagoa }\end{array}$ & $\begin{array}{c}\text { Caminhada; } \\
\text { Corrida; Ciclismo; } \\
\text { Exercícios na } \\
\text { academia ao ar livre. }\end{array}$ & $\begin{array}{c}\text { Bonito; Seguro; } \\
\text { Espaços para descanso. }\end{array}$ & Distante. \\
\hline $\begin{array}{l}\text { Parque } \\
\text { ecológico } \\
\text { Ouro Fino }\end{array}$ & $\begin{array}{c}\text { Trilhas para } \\
\text { caminhada e corrida. }\end{array}$ & Bonito; Seguro. & $\begin{array}{l}\text { Bom apenas para } \\
\text { caminhadas; Tem que } \\
\text { pagar para entrar. }\end{array}$ \\
\hline $\begin{array}{l}\text { Ginásio } \\
\text { Polentão }\end{array}$ & $\begin{array}{c}\text { Assistir modalidades } \\
\text { esportivas; Shows; } \\
\text { Teatros; Festas da } \\
\text { cidade. }\end{array}$ & $\begin{array}{l}\text { Onde acontecem } \\
\text { muitos dos eventos } \\
\text { culturais da cidade. }\end{array}$ & $\begin{array}{l}\text { Não é aberto para } \\
\text { utilização do público } \\
\text { para as atividades } \\
\text { esportivas, apenas } \\
\text { eventos e jogos de alto } \\
\text { rendimento. }\end{array}$ \\
\hline $\begin{array}{l}\text { Ginásio de } \\
\text { Esportes } \\
\text { Romano }\end{array}$ & $\begin{array}{l}\text { Participar das } \\
\text { escolinhas de } \\
\text { treinamentos }\end{array}$ & $\begin{array}{l}\text { Agendamento fácil para } \\
\text { futsal; Escolinhas de } \\
\text { modalidades } \\
\text { esportivas; Região }\end{array}$ & Focalizado em futsal. \\
\hline
\end{tabular}




\begin{tabular}{|c|c|c|c|}
\hline Zanlorenzi & esportivos. & Central. & \\
\hline $\begin{array}{l}\text { Vila } \\
\text { Olímpica } \\
\text { Antônio } \\
\text { Lacerda } \\
\text { Braga }\end{array}$ & $\begin{array}{c}\text { Participar das } \\
\text { escolinhas de } \\
\text { treinamentos } \\
\text { esportivos; Aulas de } \\
\text { natação. }\end{array}$ & $\begin{array}{c}\text { Região Central; Várias } \\
\text { modalidades. }\end{array}$ & \\
\hline $\begin{array}{c}\text { Academias ao } \\
\text { ar livre }\end{array}$ & $\begin{array}{l}\text { Exercícios com o } \\
\text { peso do corpo; } \\
\text { Exercícios de } \\
\text { alongamento. }\end{array}$ & Gratuitas. & $\begin{array}{c}\text { Desmotivante; Pouca } \\
\text { intensidade; } \\
\text { Constrangedor. }\end{array}$ \\
\hline $\begin{array}{l}\text { Academias de } \\
\text { musculação }\end{array}$ & $\begin{array}{c}\text { Musculação; Aulas } \\
\text { de ginástica; } \\
\text { Exercícios } \\
\text { aeróbicos; } \\
\text { Exercícios } \\
\text { funcionais. }\end{array}$ & $\begin{array}{l}\text { Várias modalidades; } \\
\text { Estrutura; Convívio } \\
\text { social; Resultados } \\
\text { aparentes. }\end{array}$ & $\begin{array}{c}\text { Preços altos. Falta de } \\
\text { tempo. }\end{array}$ \\
\hline $\begin{array}{l}\text { Academia de } \\
\text { Crossfit e } \\
\text { Treinamentos } \\
\text { funcionais }\end{array}$ & $\begin{array}{c}\text { Exercícios } \\
\text { funcionais; } \\
\text { Exercícios com } \\
\text { pesos; } \\
\text { Circuitos;Corridas. }\end{array}$ & $\begin{array}{l}\text { Resultados aparentes; } \\
\text { Estética; Motivante; } \\
\text { Convívio social; } \\
\text { Ambiente saudável. }\end{array}$ & Preços altos. \\
\hline $\begin{array}{l}\text { Grupos de } \\
\text { corrida }\end{array}$ & $\begin{array}{l}\text { Treinamento para } \\
\text { iniciantes e } \\
\text { avançados em } \\
\text { corrida; Corridas em } \\
\text { grupo. }\end{array}$ & $\begin{array}{l}\text { Resultados aparentes; } \\
\text { Gratuitos; Motivante; } \\
\text { Convívio social; } \\
\text { Ambiente saudável; } \\
\text { Participação de provas } \\
\text { de corrida na cidade e } \\
\text { fora; Preços baixos } \\
\text { quando pago. }\end{array}$ & $\begin{array}{l}\text { Necessidade de } \\
\text { excelente aptidão. }\end{array}$ \\
\hline $\begin{array}{l}\text { Academias de } \\
\text { natação }\end{array}$ & $\begin{array}{l}\text { Aulas de natação; } \\
\text { Hidroginástica. }\end{array}$ & Resultados aparentes. & Preços altos; Frio. \\
\hline $\begin{array}{l}\text { Escolas de } \\
\text { danças }\end{array}$ & $\begin{array}{c}\text { Aulas de balé } \\
\text { clássico; Jazz; } \\
\text { Danças latinas; Balé } \\
\text { fitness; Dança } \\
\text { gaúcha. }\end{array}$ & $\begin{array}{c}\text { Diversão; } \\
\text { Relaxamento; Preços } \\
\text { baixos; Apresentações. }\end{array}$ & $\begin{array}{l}\text { Necessária aptidão; } \\
\text { Constrangedor. }\end{array}$ \\
\hline
\end{tabular}




\subsection{PROMOÇÃO DA SAÚDE NA ESCOLA E NA COMUNIDADE}

Iniciamos essa categorização com o assunto alimentação, tal escolha ocorreu por dois motivos; o primeiro, pois concomitantemente na posição de coordenadora do curso, estava participando de alguns debates e queixas dos estudantes sobre a composição dos horários de aulas que os obrigavam a almoçar na escola ou em estabelecimentos próximos; se queixavam principalmente dos preços para realizarem refeições "saudáveis", e a distância que tinham que caminhar; o segundo motivo, pois ao responder de que maneira conceituavam saúde nos questionários, fizeram inúmeras menções sobre “alimentação” e sua relação com a saúde.

Iniciei a aula com uma brincadeira de costume, perguntando o que comeram no intervalo; quanto menos saudável, mais prazer têm em me contar sobre os lanches que fizeram e que sabem que eu darei "bronca". Temos o momento "ponto alto" em que pego a lata de lixo da sala de aula e começo a contar os pacotinhos e as latas, leio e explico "assustada" alguns rótulos, e quando encontro algum resto de fruta ou opção que considero saudável, procuro saber o dono para "parabenizá-lo", e assim brinquei nessas aulas.

Aproveitei o momento de descontração e trouxe à tona suas respostas sobre saúde, em que constantemente nos questionários relacionaram-nas com alimentação, lançando a seguinte pergunta "o que vocês comem no intervalo das aulas e no almoço entre os turnos?".

"Coxinha do posto”, "pastelão de 1 real”, "pão de queijo do terminal”, “ $x$ bacon" e "pizza" contados de forma vitoriosa foram as respostas mais frequentes. Segui com a segunda pergunta "vocês trazem lanches de casa?" pouquíssimos responderam que sim, e conforme o que eu esperava, eram aqueles que recorrentemente eram os "parabenizados" por trazer as frutas.

Quando reforcei o debate com a pergunta "por que comem o que comem e onde comem?" Alguns contaram que na hora do almoço os pais os buscavam e comiam no "intervalo de uma hora", que "era muito corrido" e foram frequentes as queixas de ser "muito pouco o tempo que tinham para almoço", que tinham "que andar”, que "não compensava ir para casa" e que não tinham opção, eles "tinham que comer o $x$ bacon".

Mediante as respostas de que proximamente só eram servidas opções pouco saudáveis, estabeleci a próxima atividade, onde os mesmos grupos de estudantes seriam 
responsáveis por fotografar os locais que vendiam lanches e refeições num raio de aproximadamente um quilômetro, com a tarefa de na próxima aula, mostrar fotos do local e contar o que eram oferecidos nesses estabelecimentos. Combinei que no horário de atendimento ao estudante eles me trariam o local escolhido, para que não ocorresse de dois grupos escolherem o mesmo e para que me certificasse que era no raio combinado de um quilômetro, usei um aplicativo de localização do celular.

E assim, nas duas aulas que se seguiram, cada grupo mostrou sua foto, nome do local e nos contou o que era servido, lancei duas perguntas "dos estabelecimentos escolhidos por vocês, é possível comprar e fazer lanches e refeições saudáveis? "Vocês os consomem? Por que".

Fiz um quadro separadamente com cada uma das turmas, e a união das respostas formou o quadro 8 .

Quadro 8 - Estabelecimentos locais para realizar refeições.

\begin{tabular}{|c|c|c|c|}
\hline \multicolumn{4}{|c|}{ Estabelecimentos locais para realizar refeições } \\
\hline Estabelecimentos & O que oferecem & $\begin{array}{l}\text { Aspectos } \\
\text { Positivos }\end{array}$ & Aspectos Negativos \\
\hline Cantina da Escola & $\begin{array}{l}\text { Salgados assados. Sanduíches } \\
\text { frios. Biscoitos. Doces em } \\
\text { geral. Café. Leite. } \\
\text { Refrigerantes. Sucos } \\
\text { industrializados. }\end{array}$ & Comodidade & $\begin{array}{c}\text { Alguns salgados acabam. } \\
\text { Preços maiores do que outros } \\
\text { lugares nas proximidades. } \\
\text { Alguns alimentos } \\
\text { industrializados passam do } \\
\text { prazo de validade. Não tem } \\
\text { frituras. }\end{array}$ \\
\hline $\begin{array}{l}\text { Lanchonete } 1 \\
\qquad(30 \mathrm{~m})\end{array}$ & $\begin{array}{l}\text { Refeições por buffet livre. } \\
\text { Sanduíches quentes. Sucos } \\
\text { naturais. Refrigerantes. } \\
\text { Bebidas alcoólicas }\end{array}$ & $\begin{array}{c}\text { Proximidade. } \\
\text { Sanduíches } \\
\text { saborosos. } \\
\text { Refeições baratas. }\end{array}$ & Sanduíches com preços altos. \\
\hline
\end{tabular}




\begin{tabular}{|c|c|c|c|}
\hline $\begin{array}{l}\text { Café e lanchonete } 2 \\
\qquad(300 \mathrm{~m})\end{array}$ & $\begin{array}{l}\text { Café. Leite. Refrigerantes. } \\
\text { Sucos industrializados. } \\
\text { Bebidas alcoólicas } \\
\text { Salgadinhos. Biscoitos. } \\
\text { Salgados fritos. Pão de queijo. }\end{array}$ & Salgados baratos. & Baixa qualidade. \\
\hline $\begin{array}{l}\text { Café e lanchonete } 3 \\
\qquad(350 \mathrm{~m})\end{array}$ & $\begin{array}{c}\text { Doces. Tortas. Sanduíches. } \\
\text { Salgados fritos e assados. } \\
\text { Café. Leite. Suco natural e } \\
\text { industrializado. Refrigerantes. } \\
\text { Bebidas alcoólicas. Doces em } \\
\text { geral. }\end{array}$ & $\begin{array}{l}\text { Proximidade com } \\
\text { o campus. } \\
\text { Qualidade dos } \\
\text { produtos. } \\
\text { Ambiente } \\
\text { agradável. }\end{array}$ & Preços altos. \\
\hline $\begin{array}{l}\text { Quitanda e Café } 1 \\
\qquad(450 \mathrm{~m})\end{array}$ & $\begin{array}{c}\text { Produtos de Hortifruti. } \\
\text { Produtos de padaria. Doces. } \\
\text { Salgados fritos e assados. } \\
\text { Tortas. Frios. Sanduíches frios } \\
\text { e quentes. Café. Leite. } \\
\text { Iogurtes. Refrigerantes. Sucos } \\
\text { industrializados e naturais. }\end{array}$ & $\begin{array}{l}\text { Variedade. Frutas } \\
\text { com preços } \\
\text { baixos. }\end{array}$ & $\begin{array}{l}\text { Atendimento ruim. Poucas } \\
\text { mesas. }\end{array}$ \\
\hline $\begin{array}{l}\text { Restaurante por } \\
\text { quilo } 1(500 \mathrm{~m})\end{array}$ & $\begin{array}{l}\text { Sanduíches quentes. Pastéis. } \\
\text { Salgados fritos. Pratos feitos. } \\
\text { Refrigerantes. Sucos } \\
\text { industrializados. }\end{array}$ & $\begin{array}{l}\text { Baixos preços. } \\
\text { Rápido } \\
\text { atendimento. } \\
\text { Comida saborosa. }\end{array}$ & Comida pesada. \\
\hline $\begin{array}{l}\text { Supermercado } \\
\qquad(450 \mathrm{~m})\end{array}$ & $\begin{array}{l}\text { Alimentos de todos os setores. } \\
\text { Rotisserie. Sanduíches frios. } \\
\text { Produtos de padaria. } \\
\text { Hortifruti. }\end{array}$ & $\begin{array}{l}\text { Proximidade com } \\
\text { o campus. } \\
\text { Possibilidade de } \\
\text { bons preços. } \\
\text { Variedade. }\end{array}$ & $\begin{array}{l}\text { Preguiça de enfrentar fila do } \\
\text { caixa. Caso comprem } \\
\text { comida prontas não têm local } \\
\text { para fazer as refeições. }\end{array}$ \\
\hline
\end{tabular}




\begin{tabular}{|c|c|c|c|}
\hline Padaria $(500 \mathrm{~m})$ & $\begin{array}{l}\text { Pães. Doces. Salgados fritos e } \\
\text { assados. Tortas. Frios. } \\
\text { Sanduiches frios. Café. Leite. } \\
\text { Iogurtes. Refrigerantes. Sucos } \\
\text { industrializados. }\end{array}$ & $\begin{array}{l}\text { Produtos de boa } \\
\text { qualidade. } \\
\text { Produtos } \\
\text { saborosos. }\end{array}$ & $\begin{array}{c}\text { Poucos lugares para sentar. } \\
\text { Preços altos. }\end{array}$ \\
\hline $\begin{array}{l}\text { Quitanda } 2 \\
(500 \mathrm{~m})\end{array}$ & Produtos de hortifrúti. & Saudável. & $\begin{array}{l}\text { Não tem lugar para se sentar. } \\
\text { Constrangimento de levar } \\
\text { poucas frutas. }\end{array}$ \\
\hline $\begin{array}{l}\text { Loja de produtos } \\
\text { naturais } 1(500 \mathrm{~m})\end{array}$ & $\begin{array}{l}\text { Frutas secas. Barrinhas de } \\
\text { cereais caseiras. Pães } \\
\text { integrais. Laticínios. Biscoitos } \\
\text { integrais. }\end{array}$ & $\begin{array}{l}\text { Produtos } \\
\text { saudáveis. } \\
\text { Próximo ao } \\
\text { campus. }\end{array}$ & $\begin{array}{c}\text { Produtos pouco saborosos. } \\
\text { Preços altos. }\end{array}$ \\
\hline $\begin{array}{l}\text { Loja de Produtos } \\
\qquad \begin{array}{c}\text { Naturais } 2 \\
(600 \mathrm{~m})\end{array}\end{array}$ & $\begin{array}{l}\text { Frutas secas. Barrinhas de } \\
\text { cereais caseiras. Pães } \\
\text { integrais. Laticínios. Biscoitos } \\
\text { integrais. }\end{array}$ & $\begin{array}{l}\text { Produtos } \\
\text { saudáveis. } \\
\text { Próximo ao } \\
\text { campus. }\end{array}$ & $\begin{array}{c}\text { Produtos pouco saborosos. } \\
\text { Preços altos. }\end{array}$ \\
\hline $\begin{array}{l}\text { Restaurante por } \\
\text { quilo } 2(600 \mathrm{~m})\end{array}$ & $\begin{array}{l}\text { Refeições por quilo. Sucos } \\
\text { naturais e industrializados. } \\
\text { Sobremesas. Refrigerantes. } \\
\text { Sorvetes. }\end{array}$ & Comida Saudável & $\begin{array}{l}\text { Negativos: Distante. Não } \\
\text { têm companhia para ir. }\end{array}$ \\
\hline $\begin{array}{l}\text { Estabelecimento de } \\
\qquad \text { Açaí } \\
(600 \mathrm{~m})\end{array}$ & Tapiocas e tigelas de açaí. & $\begin{array}{l}\text { Produtos bem } \\
\text { saborosos. Preços } \\
\text { baixos. }\end{array}$ & $\begin{array}{c}\text { Um pouco distante. Lanches } \\
\text { leves. }\end{array}$ \\
\hline $\begin{array}{l}\text { Restaurante por } \\
\text { quilo } 3(600 \mathrm{~m})\end{array}$ & $\begin{array}{l}\text { Refeições por buffet livre. } \\
\text { Refrigerantes. Sucos naturais } \\
\text { e industrializados. }\end{array}$ & $\begin{array}{l}\text { Comida saborosa } \\
\text { e à vontade. } \\
\text { Variedade. }\end{array}$ & $\begin{array}{l}\text { Preço um pouco caro. Um } \\
\text { pouco distante. }\end{array}$ \\
\hline
\end{tabular}

Débora Navarro Rocha, 2017 
Ao reler o quadro com as turmas, procurei não realizar nenhuma orientação, os próprios fizeram comentários sobre a distância equivalente de "locais saudáveis" e o "pastelão", ouvi frases de "ah, professora, mas quem vai comprar frutas na hora do intervalo?", "se for para eu ir até o mercado eu compro o bolo de chocolate”, "eu não trago nem meu caderno, vou trazer lanche de casa?".

Aquele momento para mim foi bastante claro que escolher entre um lugar ou outro para se alimentar não era apenas uma questão de distância, afinal as frutarias e os restaurantes por quilo, por exemplo, tinham uma distância quando comparados às lanchonetes; também não era uma simples questão de identificarem ou não quais alimentos ou escolhas seriam mais saudáveis, eles têm esses conhecimentos, discutem com propriedade sobre eles, mas noto que ainda existe um abismo de barreiras entre o conhecimento que têm e seus comportamentos.

Talvez as respostas que levantaram como "constrangimento em pegar frutas", "preguiça de enfrentar fila do caixa”, falta de "local para fazer as refeições compradas", "produtos pouco saborosos" e "preços" não correspondam com questões mais profundas que entendo que meu câmpus, e por que não estender, a sociedade contemporânea enfrentam, como por exemplo, o fato de oferecermos um curso que oferece aulas, atendimentos e projetos de manhã e tarde, mas não possui um refeitório; ou a realidade de uma escola e de um país em que grande parte de seus estudantes não podem contar com um valor mensal para realizarem refeições de verdade em restaurantes, escolhendo opções mais baratas, o "pão de queijo" e a "coxinha" de fato são mais baratos, ou ainda questões sobre o quão atraentes, baratos e saborosos são alguns alimentos, principalmente os industrializados.

Com vistas a conhecer as maneiras que os estudantes pensam que a promoção da saúde deva ocorrer na escola e na comunidade e ao realizar a leitura das respostas sobre o conceito de Saúde, dois aspectos chamam atenção, primeiramente a frequência com que associam com aspectos da alimentação e em segundo lugar com as autopercepções, mencionados através de palavras como "bem estar", "bem estar mental" e "saúde psicológica".

É perceptível a associação que fazem entre Saúde (Quadros 9 e 10) e responsabilidade que o indivíduo tem ou deveria ter em relação aos seus comportamentos, principalmente na esfera biológica, exemplificados através da "alimentação", "prática de atividades físicas" e "cuidados com o corpo". Em nenhuma das respostas sobre o conceito de Saúde houve associações com aspectos dos 
ambientes físico, social, econômico, político e cultural.

Quadro 9 - Conceito de Saúde - Meninas

\begin{tabular}{|c|c|}
\hline & Conceito de Saúde \\
\hline 1 & $\begin{array}{l}\text { É bem estar, estar em dia com atividades físicas, alimentação, sono, é um conjunto } \\
\text { de ações que nos beneficiam. }\end{array}$ \\
\hline 2 & $\begin{array}{l}\text { Saúde envolve todos os aspectos no que diz em relação ao funcionamento do nosso } \\
\text { corpo. }\end{array}$ \\
\hline 3 & $\begin{array}{l}\text { Que na vida tudo é feita por saúde, cuidado com sua vida e alimentação, no seu } \\
\text { cuidado com tudo. }\end{array}$ \\
\hline 4 & $\begin{array}{l}\text { É ter qualidade de vida, ausência de doenças, é estar bem fisicamente e } \\
\text { emocionalmente. }\end{array}$ \\
\hline 5 & $\begin{array}{l}\text { Saúde é quando você se sente bem pela sua alimentação e se sente bem } \\
\text { psicologicamente. }\end{array}$ \\
\hline 6 & $\begin{array}{l}\text { É tudo aquilo que envolve alimentação, físico, e saúde mental. Saúde é ter uma } \\
\text { educação alimentar boa, educação sobre os conceitos físicos que devemos ter e } \\
\text { saúde mental que é necessário para tudo citado acima funcione. }\end{array}$ \\
\hline 7 & Ser ativo, fazer práticas de exercícios, se alimentar bem. \\
\hline 8 & $\begin{array}{l}\text { Ter saúde é estar contente com os aspectos de nossas vidas como alimentação, vida } \\
\text { social, vida escolar, sentindo-se equilibrada. }\end{array}$ \\
\hline 9 & $\begin{array}{l}\text { Em meu ponto de vista, saúde é você estar de bem com o seu corpo, em questão de } \\
\text { uma boa alimentação para estar imune a certos problemas como o colesterol. Mas } \\
\text { saúde não é apenas isso relacionado à alimentação, e sim relacionado também a } \\
\text { uma saúde mental (psicológica). }\end{array}$ \\
\hline 10 & $\begin{array}{l}\text { É o estado que nos encontramos quando estamos bem, tanto no físico como no } \\
\text { emocional. Tudo é um conjunto, o corpo se relaciona com a mente, assim como a } \\
\text { mente com o corpo. }\end{array}$ \\
\hline 11 & É estar bem fisicamente e mentalmente. \\
\hline 12 & $\begin{array}{l}\text { É o estado de espirito de uma pessoa, a sua qualidade de vida, o quanto ela está } \\
\text { satisfeita com a maneira que vive e não só estar livre de doenças. }\end{array}$ \\
\hline 13 & $\begin{array}{l}\text { Conjunto de aspectos de um indivíduo (psíquico, físicos, espirituais) que ao } \\
\text { trabalharem em equilíbrio faz uma pessoa ser saudável ou não. }\end{array}$ \\
\hline 14 & $\begin{array}{l}\text { É não ter aquele corpo perfeito e sim uma mente sadia e sim não ter problemas de } \\
\text { saúde, é se sentir bem. }\end{array}$ \\
\hline 15 & $\begin{array}{l}\text { Saúde é você estar bem com você mesmo, não só pelo fato de não estar doente, } \\
\text { mas por estar feliz com a vida que leva. }\end{array}$ \\
\hline 16 & $\begin{array}{l}\text { Além de resultados médicos, é se sentir bem consigo mesmo e com as pessoas que } \\
\text { estão ao seu redor, é ser feliz, ter autoestima e querer se cuidar. }\end{array}$ \\
\hline 17 & Bem estar físico e psicológico, estar bem e se sentir bem. \\
\hline 18 & $\begin{array}{l}\text { ológico, sentir-se bem consigo mesmo (mente e } \\
\text { llta. }\end{array}$ \\
\hline
\end{tabular}

Débora Navarro Rocha, 2017

Quadro 10 - Conceito de Saúde - Meninos

\begin{tabular}{|l|l|}
\hline \multicolumn{2}{|c|}{ Conceito de Saúde } \\
\hline 1 & Uma vida boa, sem doenças, com uma alimentação boa. \\
\hline 2 & É se cuidar, comendo alimento saudável, praticando exercício físico. \\
\hline 3 & $\begin{array}{l}\text { Uma boa alimentação, exercícios regulares, para ter uma saúde psicológica, viver } \\
\text { bem, sem muito stress durante o dia a dia. }\end{array}$ \\
\hline
\end{tabular}




\begin{tabular}{|c|c|}
\hline 4 & $\begin{array}{l}\text { É um conjunto de coisas como bem estar, principalmente viver bem, ou seja, feliz e } \\
\text { claro, não ter doenças. }\end{array}$ \\
\hline 5 & É estar saudável física e mentalmente. \\
\hline 6 & $\begin{array}{l}\text { É quando seu organismo está totalmente de acordo, com os níveis de glicose entre } \\
\text { outros bem regulados. Também é a alimentação, a forma de vida, psicológico, etc. }\end{array}$ \\
\hline 7 & $\begin{array}{l}\text { É o bem estar, não apenas dos órgãos, mas também um bem estar psicológico, ou } \\
\text { seja, saúde é estar sem doenças no corpo e na alma. }\end{array}$ \\
\hline 8 & $\begin{array}{l}\text { Estar fisicamente e mentalmente estável, assim gerando um bem estar geral. Se } \\
\text { baseia em estar e se sentir bem comigo mesmo fisicamente e mentalmente. }\end{array}$ \\
\hline 9 & $\begin{array}{l}\text { É ter uma manutenção do seu corpo tendo uma dieta rica em nutrientes e } \\
\text { praticando atividade física, garantindo qualidade de vida. }\end{array}$ \\
\hline 10 & É se alimentar bem e manter uma vida de atividades físicas e viver bem. \\
\hline 11 & $\begin{array}{l}\text { Estar bem tanto fisicamente quanto mentalmente, no caso, se sentir bem como você } \\
\text { é. }\end{array}$ \\
\hline 12 & Cuidar do seu corpo. \\
\hline 13 & $\begin{array}{l}\text { É quando você está em pleno funcionamento fisicamente, mentalmente e } \\
\text { espiritualmente, saúde é você estar bem, não sentir desconforto. }\end{array}$ \\
\hline 14 & $\begin{array}{l}\text { Na saúde podemos ser saudáveis ou não saudáveis, ter bons hábitos alimentares e } \\
\text { entre outros itens ajudam a ser saudável, caso contrário, sinto muito. }\end{array}$ \\
\hline 15 & Bem estar físico, mental e espiritual. \\
\hline 16 & $\begin{array}{l}\text { Conjunto de bem estar, boa alimentação, prática de atividades físicas, sem prejuízo } \\
\text { ao corpo humano, etc. }\end{array}$ \\
\hline 17 & $\begin{array}{l}\text { Não é só viver sem doenças, é também viver saudável (praticar esportes, comer } \\
\text { bem). }\end{array}$ \\
\hline 18 & $\begin{array}{l}\text { Saúde ou ter saúde é quando uma pessoa não tem doenças, ela pratica alguma } \\
\text { atividade física e se sente bem com o seu corpo. }\end{array}$ \\
\hline 19 & Comer alimentos saudáveis, praticar exercícios físicos, levar uma vida controlada. \\
\hline 20 & Bem estar geral, fisicamente e psicologicamente. \\
\hline 21 & $\begin{array}{l}\text { O conjunto de uma boa alimentação, prática de exercícios físicos e imunidade às } \\
\text { doenças. }\end{array}$ \\
\hline 22 & $\begin{array}{l}\text { Para ser saudável, acho que tem que ter uma boa alimentação, praticar atividades } \\
\text { físicas. Acho que saúde é como você está se sentindo. }\end{array}$ \\
\hline 23 & $\begin{array}{l}\text { Saúde é você poder sentir-se bem, estar tranquilo. Colocar em mente que viver é } \\
\text { bom e saber viver em sociedade. }\end{array}$ \\
\hline 24 & $\begin{array}{l}\text { Saúde é o que a pessoa acha que é saudável, cada pessoa pensa algo, como } \\
\text { atividade física. }\end{array}$ \\
\hline 25 & $\begin{array}{l}\text { Esporte (pratica de atividade física), saúde mental, ou seja, a pessoa tem que estar } \\
\text { com a cabeça boa para ter saúde. }\end{array}$ \\
\hline 26 & o conceito de saúde ao meu ver é se manter bem fisicamente e mentalmente. \\
\hline 27 & É a situação física e psicológica de uma pessoa. \\
\hline 28 & $\begin{array}{l}\text { É bem estar com ela mesma, uma saúde mental, uma saúde física, é a pessoa estar } \\
\text { saudável com seus aspectos. }\end{array}$ \\
\hline 29 & $\begin{array}{l}\text { É o conjunto de fatores que juntos são capazes de proporcionar uma boa qualidade } \\
\text { de vida. }\end{array}$ \\
\hline 30 & $\begin{array}{l}\text { Estar bem consigo mesmo, ou com os outros, existem a saúde física, mental e } \\
\text { social. Falar de saúde no geral é muito complexo, mas saúde significa ser feliz, ou } \\
\text { saudável, etc. }\end{array}$ \\
\hline 31 & bem estar físico e emocional. \\
\hline 32 & bem com o seu corpo e estar feliz fisicamente e mentalr \\
\hline
\end{tabular}




\begin{tabular}{|l|l|}
\hline 33 & $\begin{array}{l}\text { Algo como uma boa vida, levar uma vida leve e bem regrada para estar bem } \\
\text { consigo mesmo e no ambiente em que se vive. }\end{array}$ \\
\hline 34 & Bem estar físico e mental. \\
\hline 35 & $\begin{array}{l}\text { É o que define o bem estar, seja pessoal, social. Estar bem consigo mesmo e com } \\
\text { outras pessoas. }\end{array}$ \\
\hline 36 & É estar bem com você mesmo, se alimentar bem, fazer o que gosta. \\
\hline 37 & $\begin{array}{l}\text { É você estar em condição apta para desempenhar sua rotina. É estar disposto a } \\
\text { fazer suas tarefas, estar com certa aptidão física e psicológica para trabalhar, } \\
\text { estudar, fazer esportes e não simplesmente não estar doente. }\end{array}$ \\
\hline 38 & Nada mais é do que o bem estar físico e mental. \\
\hline 39 & $\begin{array}{l}\text { Viver bem, ter uma alimentação saudável, ter uma boa noite de sono, evitar } \\
\text { problemas que causam problemas à saúde. }\end{array}$ \\
\hline 40 & $\begin{array}{l}\text { É principalmente ser saudável, ou seja, ter alimentação e atividades físicas corretas } \\
\text { e também não contrair doenças. }\end{array}$ \\
\hline 41 & $\begin{array}{l}\text { É você estar bem não apenas fisicamente, mas também bem com você mesmo, ou } \\
\text { seja moralmente. }\end{array}$ \\
\hline 42 & Se sentir bem fisicamente e psicologicamente e também estar bem. \\
\hline 43 & Se sentir bem com a vida e ao mesmo tempo ter um corpo saudável. \\
\hline 44 & É o estado da pessoa tipo se ela não está doente a saúde dela está boa. \\
\hline 45 & Viver bem, desfrutar os prazeres da vida. \\
\hline 46 & Não estar doente. \\
\hline 47 & Conjunto de costumes alimentícios e atividades físicas, ausência de doenças. \\
\hline 48 & $\begin{array}{l}\text { Ficar de bem com a vida, não só em saúde corporal, mas também saúde } \\
\text { psicológica. }\end{array}$ \\
\hline
\end{tabular}

Débora Navarro Rocha, 2017

$\mathrm{O}$ entendimento que se tem quando questionados sobre como a escola poderia ser uma promotora de saúde (Quadros 11 e 12), traz a ideia de uma grande “incentivadora”. Nas respostas dos meninos, esse "incentivo" se daria principalmente em relação à oferta de atividades físicas e esportes, tanto durante as aulas de educação física como em atividades oferecidas pela escola, bastante referenciados com as palavras "projetos", desejo novamente reforçado pela frequente referência à necessidade de espaços "adequados".

As meninas ampliam essa interpretação ao apresentar referências em que a escola poderia "incentivar" a discussão de outros assuntos como "drogas", "bem estar psicológico" "transtornos alimentares" e "interação social”, utilizam também palavras como "informação", "educação" e "conscientização".

A escola também é pretendida com uma facilitadora da alimentação saudável, através de um frequente mencionar de uma "cantina" que disponibilizasse "alimentos mais saudáveis" e por "preços acessíveis".

Quadro 11. Promoção de Saúde na escola - Meninas 


\begin{tabular}{|c|c|}
\hline \multicolumn{2}{|r|}{ Promoção de Saúde na Escola } \\
\hline 1 & $\begin{array}{l}\text { Para promover a saúde de adolescentes em ambiente escolar é necessário mais } \\
\text { intervalos para se alimentar de forma correta e em horário correto. }\end{array}$ \\
\hline 2 & $\begin{array}{l}\text { Ter aulas de educação física tanto práticas quanto sobre educação e conscientização } \\
\text { sobre alguns aspectos da vida dos adolescentes. Também discutir temas como } \\
\text { transtornos alimentares, psicológicos, sexualidade, drogas, entre outros. }\end{array}$ \\
\hline 3 & Nas escolas deveriam ter cantinas e alimento saudáveis para todos. \\
\hline 4 & $\begin{array}{l}\text { Acredito que comece pela alimentação, a escola tentar mostrar e ofertar alimentos } \\
\text { saudáveis além da saúde física é necessário observar o psicológico do adolescente, } \\
\text { pois muitas vezes pode ter problemas com os pais ou até mesmo no mundo das } \\
\text { drogas. }\end{array}$ \\
\hline 5 & Abordar mais assuntos em algumas aulas e também em palestras. \\
\hline 6 & $\begin{array}{l}\text { Conscientizá-los da importância de ter uma saúde boa, com alimentação saudável e } \\
\text { derivados. }\end{array}$ \\
\hline 7 & Ter aulas práticas de educação física todo dia da semana \\
\hline 8 & $\begin{array}{l}\text { Pode ser realizado acompanhamento psicológico com os alunos, individualmente, e } \\
\text { pode ser promovido eventos sociais, para comunicação, além de grupos de estudos. }\end{array}$ \\
\hline 9 & $\begin{array}{l}\text { Palestras, conversas, incentivos. Mas não algo que seja maçante e sim que os } \\
\text { alunos consigam interagir com o tema. }\end{array}$ \\
\hline 10 & $\begin{array}{l}\text { Ser implantada uma motivação para que haja interesse na saúde! Palestras } \\
\text { divertidas, que mostrem exemplos de pessoas saudáveis, mostrar em palestras } \\
\text { estilos de vida que dão certo, mostrar resultado. }\end{array}$ \\
\hline 11 & Práticas de atividades físicas, incentivo a boa alimentação entre outros. \\
\hline 12 & $\begin{array}{l}\text { Mais esportes no colégio, não temos espaços adequados para a prática deles, } \\
\text { promover mais atividades empolgantes e interativas também, juntando turmas ou } \\
\text { não. }\end{array}$ \\
\hline 13 & $\begin{array}{l}\text { Mostrar a ampla área de diferentes atividades físicas existentes, não só futebol ou } \\
\text { vôlei, para que vejam isso como lazer e não obrigação, e apresentar que para ser } \\
\text { saudável não precisa ser bitolado ou que é chato, mostrar na prática o bem que faz } \\
\text { e que traz muito mais benefícios do que somente um corpo sarado. }\end{array}$ \\
\hline 14 & $\begin{array}{l}\text { Ter meios onde possam comer coisas saudáveis e que tenha como não ficar tão } \\
\text { parado. Trazer lanches saudáveis. }\end{array}$ \\
\hline 15 & $\begin{array}{l}\text { Incentivar os alunos e mostrar como uma alimentação melhor ou qualquer outro } \\
\text { habito pode melhorar positivamente suas vidas. }\end{array}$ \\
\hline 16 & $\begin{array}{l}\text { Mostrando o que faz mal, alertando em algo que está fazendo incorretamente, mas } \\
\text { também sendo gentil para aumentar a autoestima. }\end{array}$ \\
\hline 17 & $\begin{array}{l}\text { Espaços em que haja comunicação entre alunos e professores, conscientização para } \\
\text { uma alimentação de qualidade, espaço adequado para práticas esportivas e } \\
\text { atividade física. }\end{array}$ \\
\hline 18 & $\begin{array}{l}\text { Atividades físicas no âmbito escolar, áreas de lazer para diminuir a tensão e o stress } \\
\text { do dia a dia, bom convívio entre alunos e professores. }\end{array}$ \\
\hline
\end{tabular}

Débora Navarro Rocha, 2017

Quadro 12 - Promoção de Saúde na escola - Meninos

\begin{tabular}{|l|l|}
\hline \multicolumn{2}{|c|}{ Promoção de Saúde na Escola } \\
\hline 1 & Vai de cada aluno saber "o que" se alimentar, por isso serve a internet. \\
\hline 2 & Alimento saudável e barato e mais exercício físico na aula de Educação Física. \\
\hline 3 & $\begin{array}{l}\text { Praticas regulares mensais de análise de peso, observações e anotações para ver } \\
\text { como vai a alimentação. }\end{array}$ \\
\hline
\end{tabular}




\begin{tabular}{|c|c|}
\hline 4 & $\begin{array}{l}\text { As escolas devem além de incentivar atividades físicas, devem fornecer uma boa } \\
\text { alimentação. }\end{array}$ \\
\hline 5 & $\begin{array}{l}\text { Realizar atividades de maior envolvimento dos alunos nas práticas dos hábitos } \\
\text { saudáveis. }\end{array}$ \\
\hline 6 & Mais aulas práticas, frutas pela manhã (fornecidas pelo colégio). \\
\hline 7 & Mais aulas de educação física e alimentação na cantina mais saudável. \\
\hline 8 & $\begin{array}{l}\text { Dar a chance para os mesmos promover incentivo, e mostrar como estar bem } \\
\text { fisicamente e mentalmente pode ser promovido por praticas simples. }\end{array}$ \\
\hline 9 & Deve ser proporcionado um tempo de atividade física no ambiente escolar. \\
\hline 10 & Um ambiente que estimule esportes, além de alimentos saudáveis e baratos. \\
\hline 11 & Programas que incentivem os adolescentes. \\
\hline 12 & $\begin{array}{l}\text { Deveriam criar cartazes, palestras dentre outras coisas, incentivando e dando dicas } \\
\text { para os jovens seguirem uma vida saudável. }\end{array}$ \\
\hline 13 & $\begin{array}{l}\text { Incentivar a pratica de exercícios durante as aulas de educação física, manter uma } \\
\text { boa alimentação e etc. }\end{array}$ \\
\hline 14 & Uma alimentação saudável por meio de uma cantina. \\
\hline 15 & Menos provas, por favor. \\
\hline 16 & Ter cantina grátis no colégio. \\
\hline 17 & $\begin{array}{l}\text { Troca de alimentos gordurosos, com glúten, por alimentos mais saudáveis, como } \\
\text { frutas, por exemplo. Além, claro, de ginásios de esportes, que permitam a prática } \\
\text { de atividades. }\end{array}$ \\
\hline 18 & Apoiar a prática de esportes, ter local para a prática e apoiar a boa alimentação. \\
\hline 19 & Ter comidas saudáveis para vender, algum lugar para relaxar e tirar o stress. \\
\hline 20 & $\begin{array}{l}\text { Falar sobre o assunto, como os exercícios são importantes, os alimentos que são } \\
\text { bons, saudáveis. }\end{array}$ \\
\hline 21 & $\begin{array}{l}\text { Comidas saudáveis mais acessíveis financeiramente na cantina, e aulas práticas de } \\
\text { edf. }\end{array}$ \\
\hline 22 & $\begin{array}{l}\text { Ter um ambiente apropriado para esportes, uma lanchonete com opções saudáveis } \\
\text { para comer e o incentivo por parte dos professores e administradores. }\end{array}$ \\
\hline 23 & $\begin{array}{l}\text { Os professores explicarem para os alunos como é importante se manter saudável, } \\
\text { ter uma alimentação saudável. }\end{array}$ \\
\hline 24 & $\begin{array}{l}\text { Alimentos de qualidade, incentivos, palestras educacionais, disponibilidade de } \\
\text { pesquisas sobre o assunto. }\end{array}$ \\
\hline 25 & Melhor alimentação, alimentos mais saudáveis. \\
\hline 26 & Aulas práticas e teóricas sobre o tema. \\
\hline 27 & Praticas de atividades físicas. \\
\hline 28 & Oferecer suporte para os adolescentes que necessitam. \\
\hline 29 & $\mathrm{O}$ incentivo de todos para que estejam bem consigo mesmos. \\
\hline 30 & Melhorar a qualidade dos alimentos da cantina, melhorar as quadras esportivas. \\
\hline 31 & $\begin{array}{l}\text { Devem ser feitas aulas/palestras para orientar os alunos, tanto sobre atividades } \\
\text { físicas ou alimentação, para que eles tenham uma noção do que é bom ou não. }\end{array}$ \\
\hline 32 & $\begin{array}{l}\text { Aulas práticas de educação física, uma boa educação sobre alimentação, e a } \\
\text { disponibilização de um espaço e materiais para a pratica de esportes em contra } \\
\text { turno. }\end{array}$ \\
\hline 33 & $\begin{array}{l}\text { Fazer check ups nas escolas, vender alimentos saudáveis na cantina, realizar } \\
\text { campeonatos entre as turmas. }\end{array}$ \\
\hline 34 & Mais práticas, alguns momentos culturais sobre essa causa. \\
\hline 35 & $\begin{array}{l}\text { A criação de um ambiente inclusivo entre os alunos, e que também seja adequado } \\
\text { para a prática de esportes. }\end{array}$ \\
\hline
\end{tabular}




\begin{tabular}{|l|l|}
\hline 36 & $\begin{array}{l}\text { Maior incentivo à pratica de atividades físicas, um exemplo são os projetos da } \\
\text { matéria de educação física, incentivo a uma boa alimentação, orientação quanto ao } \\
\text { uso de drogas. }\end{array}$ \\
\hline 37 & $\begin{array}{l}\text { Apresentar meios saudáveis, de se alimentar, de viver, de forma atrativa, sem ter } \\
\text { que explicar o que cada alimento faz, cada atividade, só mostrar que é benéfico e } \\
\text { que pode ser um meio de se divertir, descontrair. }\end{array}$ \\
\hline 38 & $\begin{array}{l}\text { Talvez um cardápio mais saudável na cantina, com preços mais em conta, já que na } \\
\text { maioria das vezes são mais caros, incentivos por meio de cartazes já eu palestras } \\
\text { são exaustivas. }\end{array}$ \\
\hline 39 & Aulas práticas. \\
\hline 40 & $\begin{array}{l}\text { Promover atividades físicas regularmente, incentivar a prática de esportes e uma } \\
\text { boa alimentação. }\end{array}$ \\
\hline 41 & $\begin{array}{l}\text { Ter um local adequado para a prática de esportes, ter uma cantina saudável e } \\
\text { estimular as pessoas a praticarem atividades. }\end{array}$ \\
\hline 42 & $\begin{array}{l}\text { As aulas de educação física são um bom começo, mas quando ela é somada com } \\
\text { projetos feitos não apenas pelos professores mas também com alunos isso pode ser } \\
\text { um ótimo caminho para promover saúde. Outra situação é a alimentação que } \\
\text { precisa ser melhorada no colégio. }\end{array}$ \\
\hline 43 & Mais práticas de esportes no ambiente escolar e mais estrutura para essas práticas. \\
\hline 44 & Mais atividades físicas e comidas saudáveis de graça. \\
\hline 45 & Campanha de bem estar, venda de produtos mais saudáveis. \\
\hline 46 & $\begin{array}{l}\text { É difícil se promover a saúde na verdade não se pode fazer nada, porque cada um } \\
\text { faz o que quer de sua vida, somos muito preguiçosos para mudar e promover nossa } \\
\text { saúde. }\end{array}$ \\
\hline 47 & Incentivar os alunos a ter uma atividade física todos os dias. \\
\hline 48 & \begin{tabular}{l} 
Uma cantina com alimentos orgânicos e plantar os alimentos consumidos. \\
\hline Deboravaro Rota,
\end{tabular} \\
\hline
\end{tabular}

Débora Navarro Rocha, 2017

Quando se apresenta a promoção da saúde na comunidade (Quadros 13 e 14), abrem-se novas discussões, não apenas sobre atividade física e a alimentação, constantemente presentes na escola, mas são mencionados, ainda que timidamente os "espaços urbanos", o "governo" e a "sociedade".

Surge a ideia de a comunidade ser um "exemplo" através de "uma nova mentalidade", "um novo estilo de vida", "uma transformação total” e "uma atmosfera saudável”. Surgem também apontamentos sobre o uso e demandas dos espaços públicos, como "melhor atendimento dos hospitais", "segurança, manutenção e principalmente zelo pela área que está sendo utilizada”, e questões não muito frequentes, mas passíveis de um extremo cuidado como "enfermeiros e psiquiatras nas escolas" e "projetos da prefeitura para trabalhar com ansiedade e depressão dos adolescentes". 
Quadro 13 - Promoção de Saúde na Comunidade - Meninas

\begin{tabular}{|c|c|}
\hline \multicolumn{2}{|r|}{ Promoção de Saúde na Comunidade } \\
\hline 1 & $\begin{array}{l}\text { Projetos de incentivo a alimentação, palestras para ressaltar a importância de } \\
\text { dormir, comer bem e se exercitar. }\end{array}$ \\
\hline 2 & Investir em segurança e em projetos de otimização dos espaços urbanos. \\
\hline 3 & Ter restaurantes e lanchonetes com alimentos saudáveis. \\
\hline 4 & $\begin{array}{l}\text { União entre todos, o conceito de saúde deve ser o objetivo, pois juntos é muito } \\
\text { mais fácil. }\end{array}$ \\
\hline 5 & Não respondeu. \\
\hline 6 & $\begin{array}{l}\text { Mobilizar ações de praticas para uma saúde melhor, como ajuda na consciência de } \\
\text { ingerir alimentos saudáveis. }\end{array}$ \\
\hline 7 & Mais campos para se realizar as atividades, \\
\hline 8 & $\begin{array}{l}\text { Pode ser realizado eventos sociais que promovem uma boa alimentação, feiras } \\
\text { gastronômicas, palestras sobre saúde mental, social... e outros que estarão } \\
\text { informando a população/comunidade sobre diversos temas. }\end{array}$ \\
\hline 9 & Melhoramento nas estruturas oferecidas pelo município. \\
\hline 10 & $\begin{array}{l}\text { Ser implantada uma nova mentalidade, um novo estilo de vida na maioria dos } \\
\text { adolescentes, mostrar que uma alimentação saudável e atividade física são segredos } \\
\text { do sucesso, sucesso da vida. }\end{array}$ \\
\hline 11 & $\begin{array}{l}\text { Incentivo às práticas de atividades físicas, promover palestras sobre saúde, fornecer } \\
\text { ambientes para as práticas e aulas gratuitas. }\end{array}$ \\
\hline 12 & Ambientes públicos para o esporte, melhor atendimento dos hospitais. \\
\hline 13 & $\begin{array}{l}\text { Tudo começa em casa, principalmente com exemplos, é um problema, impregnado } \\
\text { na nossa sociedade e dificilmente os pais mudam, começar pelas crianças, porque } \\
\text { ela vai crescer de acordo com o ensinado. }\end{array}$ \\
\hline 14 & Campanhas onde mostrem o quanto faz mal a vida que muitos levam. \\
\hline 15 & $\begin{array}{l}\text { Disponibilizar consultórios móveis com mais estruturação, pois os que temos estão } \\
\text { ruins. }\end{array}$ \\
\hline 16 & Dando exemplos de como ser saudável e os animando, sendo gentil e educado. \\
\hline 17 & $\begin{array}{l}\text { Projetos de iniciativa pública e ou privada, para o bem estar de todos os moradores } \\
\text { da comunidade. }\end{array}$ \\
\hline 18 & Um ambiente agradável visualmente, parques áreas de convivência. \\
\hline
\end{tabular}

Débora Navarro Rocha, 2017

Quadro 14 - Promoção de Saúde na Comunidade - Meninos

\begin{tabular}{|l|l|}
\hline \multicolumn{2}{|c|}{ Promoção de Saúde na Comunidade } \\
\hline 1 & Cartazes ilustrativos. \\
\hline 2 & $\begin{array}{l}\text { Na minha comunidade quase não tem adolescente. (possibilidade de entendimento } \\
\text { de comunidade como algo mais restrito, como seu bairro). }\end{array}$ \\
\hline 3 & A melhora do atendimento em postos de saúde e hospitais. \\
\hline 4 & $\begin{array}{l}\text { O governo deve fazer campanhas, além disso, criar projetos para os jovens não } \\
\text { entrarem em depressão. }\end{array}$ \\
\hline 5 & Facilitar o acesso das pessoas a principalmente, comidas mais saudáveis. \\
\hline 6 & Encontros, como encontro de ciclistas. \\
\hline 7 & $\begin{array}{l}\text { Acho que um governo mais ativo para fazer campanha sobre alimentação e } \\
\text { cuidados. }\end{array}$ \\
\hline 8 & Uma transformação total no estilo de vida sedentário, triste e depressivo. \\
\hline 9 & $\begin{array}{l}\text { Construção de espaços para realização de atividade física e orientações para suas } \\
\text { realizações. }\end{array}$ \\
\hline
\end{tabular}




\begin{tabular}{|c|c|}
\hline 10 & Uma atmosfera saudável sem duvida é essencial para estimular uma vida saudável. \\
\hline 11 & Mais parques e programas. \\
\hline 12 & $\begin{array}{l}\text { Para promover a saúde de adolescentes na comunidade, poderiam ser criados } \\
\text { projetos e ambientes esportivos para os jovens. }\end{array}$ \\
\hline 13 & $\begin{array}{l}\text { Mais investimentos em postos de saúde próximos às comunidades, mais áreas de } \\
\text { lazer. }\end{array}$ \\
\hline 14 & Campanhas sobre depressão. \\
\hline 15 & Limitar a internet. \\
\hline 16 & Aumentar as atividades esportivas. \\
\hline 17 & $\begin{array}{l}\text { Mais espaços para lazer, como parques, onde as pessoas possam se movimentar se } \\
\text { divertindo, mais oportunidades de atividades físicas, etc. }\end{array}$ \\
\hline 18 & Apoiar a boa alimentação. \\
\hline 19 & $\begin{array}{l}\text { Um parque que tenha como fazer exercícios e relaxar, e incentivos para comidas } \\
\text { saudáveis. }\end{array}$ \\
\hline 20 & $\begin{array}{l}\text { Cada um ter a consciência do que ira fazer e comer, mas é algo que não tem muito } \\
\text { o que fazer. Acho que isso depende de cada pessoa, a pessoa pode estar feliz do } \\
\text { jeito que está, mas como vi em uma cidade do leste há um tempo, haviam aulas de } \\
\text { dança gratuitas no centro da cidade e era um ambiente bem animado, acho que esse } \\
\text { ânimo incentiva as pessoas a se cuidarem mais. }\end{array}$ \\
\hline 21 & $\begin{array}{l}\text { Ter parques e quadras para praticar esportes e socializar, além de conscientizá-los } \\
\text { sobre a alimentação. }\end{array}$ \\
\hline 22 & Promover campanhas, em questão da saúde das pessoas. \\
\hline 23 & Conscientizar as pessoas que saúde é necessário para todos e é muito importante. \\
\hline 24 & Conscientização alimentar e infraestrutura para conseguir ser mais saudável. \\
\hline 25 & $\begin{array}{l}\text { Projetos esportivos para a comunidade seriam bem interessantes, pois só a escola } \\
\text { não dá conta de promover "saúde". }\end{array}$ \\
\hline 26 & Palestras sobre depressão em jovens. \\
\hline 27 & Conscientização das pessoas ao seu redor. \\
\hline 28 & Numa boa consciência na sociedade. \\
\hline 29 & Enfermeiros e psiquiatras nas escolas \\
\hline 30 & $\begin{array}{l}\text { Ter espaços próximos, postos d saúde, hospitais, e ter uma orientação do governo } \\
\text { para as pessoas. E também as pessoas tomarem consciência de sua saúde, como } \\
\text { cuidá-la. }\end{array}$ \\
\hline 31 & $\begin{array}{l}\text { Promover meios de comunicação (folders, cartazes) para que seja disseminada a } \\
\text { importância de coisas fundamentais à nossa saúde, tais como a boa alimentação e a } \\
\text { prática de esportes. }\end{array}$ \\
\hline 32 & $\begin{array}{l}\text { Construir postos de saúde, incentivar a higiene, distribuir camisinhas } \\
\text { gratuitamente. }\end{array}$ \\
\hline 33 & $\begin{array}{l}\text { Avisos em cartazes, movimentos para melhorar a qualidade de vida como passeios } \\
\text { ciclísticos, corridas como maratonas, etc. }\end{array}$ \\
\hline 34 & $\begin{array}{l}\text { Propagandas sobre os inúmeros benefícios que uma boa alimentação e a pratica } \\
\text { regular de atividades físicas faze. }\end{array}$ \\
\hline 35 & $\begin{array}{l}\text { Informação, não vejo ninguém falando para as pessoas se cuidarem e se } \\
\text { alimentarem melhor. }\end{array}$ \\
\hline 36 & $\begin{array}{l}\text { Horários para as práticas desses esportes, segurança, manutenção e principalmente } \\
\text { zelo pela área que está sendo utilizada, já que é um local público. }\end{array}$ \\
\hline 37 & Centros esportivos. \\
\hline 38 & Outdoor e panfletos de prevenção contra doenças e incentivar a prática de esportes. \\
\hline 39 & Na comunidade em geral em minha opinião é boa, mas como só jogo futebol em \\
\hline
\end{tabular}




\begin{tabular}{|l|l|}
\hline & $\begin{array}{l}\text { um todo é meio ruim, pois não têm tantos lugares para corrida, vôlei, basquete, mas } \\
\text { os lugares que têm são muito perigosos e lanchonetes saudáveis. }\end{array}$ \\
\hline 40 & Projetos feitos pelas prefeituras na conscientização da população. \\
\hline 41 & Mais adolescentes praticando esportes e mais estruturas. \\
\hline 42 & $\begin{array}{l}\text { Programas fornecidos pela prefeitura onde a pessoa pode se sentir relaxada ou que } \\
\text { promovam aulas básicas sobre alimentação. }\end{array}$ \\
\hline 43 & Projetos da prefeitura para trabalhar com ansiedade e depressão dos adolescentes. \\
\hline 44 & $\begin{array}{l}\text { Deveria existir projetos que levem a informação mas o interesse tem que partir de } \\
\text { cada um. }\end{array}$ \\
\hline 45 & Oferecer recursos para eles terem acesso a esse tipo de atividade. \\
\hline 46 & Uma horta publica e mais ciclovias. \\
\hline 47 & Uma boa convivência, além de um lugar sem tanta poluição. \\
\hline 48 & Cartazes ilustrativos. \\
\hline
\end{tabular}

Débora Navarro Rocha, 2017

Nas aulas que se seguiram, o objetivo foi de promover uma conversa sobre quais conhecimentos relacionados à saúde os estudantes tinham interesse e de que maneira gostariam que fossem desenvolvidos na escola e na comunidade; quando perguntados "Vocês se interessam por conteúdos relacionados à saúde?" a resposta foi quase unânime, forte e constante de que sim, se interessam e gostam, mas quase sempre essas respostas vieram acompanhadas de "mas eu não consigo ser saudável", "é muito frustrante", "não sei por onde começar” e enumeraram vários conteúdos que gostariam de um maior aprofundamento.

Seguindo, quando perguntados sobre a "forma como os conhecimentos sobre saúde chegam até vocês?" e de que forma "esses conhecimentos poderiam chegar até vocês de forma mais interessante”, compõem o quadro que se segue.

Quadro 15 - Meios que obtêm conteúdos sobre saúde. Sugestões de conteúdos para aprofundamento. Sugestões de metodologias.

\begin{tabular}{|l|l|l|}
\hline \multicolumn{2}{|c|}{$\begin{array}{r}\text { Meios que obtêm conteúdos sobre saúde. Sugestões de conteúdos para } \\
\text { aprofundamento. Sugestões de metodologias. }\end{array}$} \\
\hline $\begin{array}{l}\text { Meios de } \\
\text { Informação }\end{array}$ & $\begin{array}{l}\text { Conteúdos para } \\
\text { aprofundamento }\end{array}$ & Metodologias \\
\hline $\begin{array}{l}\text { Aulas de } \\
\text { Educação } \\
\text { Física }\end{array}$ & Como dormir melhor & Aprender a realizar exercícios físicos diferentes \\
\hline
\end{tabular}




\begin{tabular}{|l|l|l|}
\hline Cartazes & Como perder gordura & Aulas de relaxamento \\
\hline Facebook & $\begin{array}{l}\text { Como procurar boas } \\
\text { informações online sobre } \\
\text { saúde }\end{array}$ & Aulas na horta agroecológica da escola \\
\hline Família & Diminuir ansiedade & Aulas práticas de culinária \\
\hline Instagram & $\begin{array}{l}\text { Exercícios para se realizar } \\
\text { em casa }\end{array}$ & Aulas teóricas descontraídas \\
\hline $\begin{array}{l}\text { Manchetes em } \\
\text { sites }\end{array}$ & $\begin{array}{l}\text { Receitas saudáveis e } \\
\text { gostosas }\end{array}$ & Caminhadas nas trilhas dos parques com a turma \\
\hline Revistas & Suplementos alimentares & Continuidade dos projetos esportivos \\
\hline Snapchat & Transtornos alimentares & Experimentar modalidades em academias \\
\hline Televisão & Dietas & Jogos intersalas nos parques e ginásios da cidade \\
\hline & $\begin{array}{l}\text { Nos horários de atendimentos aos estudantes } \\
\text { conversar de maneira privada sobre dieta e } \\
\text { exercícios }\end{array}$ \\
\hline
\end{tabular}

Débora Navarro Rocha, 2017 


\section{DISCUSSÃO}

Participar é tomar partido em alguma coisa.

Participar é fazer parte de alguma coisa.

Participar é organizar-se com os outros para serem responsáveis conjuntamente pelo máximo de aspectos que constituem a nossa vida.

Participar é sentir-se soberano.

Participar é algo político, um jogo democrático.

Participar não é uma finalidade, mas um meio que nos ajuda a tomar consciência da realidade.

Participar é ser protagonista e solidário ao mesmo tempo, para mudar a partir do compartilhar.

Participar é a capacidade de dar e de receber. Eu saio de mim, me expresso como sou e sou permeável.

Participar é a capacidade de assumir dificuldades, incômodos e gozar a vida.

Participar não é apenas decidir, mas trabalhar.

Participar não é só falar, é também ouvir,

Participar é acreditar que o projeto é importante. (Muñoz, 2004, p. 91)

A tarefa de realizar essa pesquisa me trouxe algumas oportunidades interessantes. A primeira foi estreitar os laços que tinha com meus estudantes, algo que já considerava um ponto notável em nossa relação.

Estar na coordenação do curso, oportunizou muitos momentos de diálogos com os estudantes, constantemente incentivados pela gestão do campus, que tem como preconização o fortalecimento da gestão democrática. Dentre as ações dessa gestão, destaca-se a criação do Conselho de Representantes de Turmas - CRT como instância representativa do segmento discente junto às unidades executivas do campus.

O CRT é o nosso canal de participação social mais importante, ao oferecer aos estudantes a possibilidade em opinar e contribuir com decisões sobre as ações pedagógicas, administrativas e disciplinares legitimando suas participações nas reuniões do CRT, nos coletivos pedagógicos que ocorrem aos finais de bimestre e nas reuniões do Colégio Dirigente do Câmpus - CODIC, órgão de apoio técnico-político à gestão do campus, com representação dos três segmentos da comunidade escolar, estudantes, docentes e técnicos administrativos.

Dessa forma, não poderia discutir os resultados sem destacar que me deparei e dialoguei com estudantes que em sua maioria demonstrou desenvoltura ao se expressar e no quanto esses exercícios de diálogos com a gestão têm contribuído às suas formações política, social e cultural.

Munida com a pretensão de que eu conduziria o diálogo com minhas intervenções e roteiro, me reconheci em muitos momentos no orgulhoso papel de 
espectadora de grandes facilitadores do diálogo.

Ao ler e vivenciar os resultados durante as discussões, mais do que conhecer sobre como pensam a promoção da saúde e da atividade física, avaliei minha contribuição a esses resultados e pude aprender com a experiência dos meus estudantes, de acordo com Moreira (2009), isso ocorre à medida que o professor incorpora novos significados à sua estrutura cognitiva, por meio de intercâmbios constantes entre ele, os conteúdos e o aluno, constituindo um processo de contínua atualização e reformulação frente às diferentes demandas e cenários culturais trazidos pelos seus alunos.

Discutirei os resultados com os princípios da promoção da saúde, de forma a nos reconhecermos (comunidade, escola, componente curricular) esferas passíveis de melhoramentos.

Esses princípios, de acordo com o art. $4^{\circ}$ da portaria $\mathrm{n}^{\circ} 2.446$, DE $11 \mathrm{DE}$ NOVEMBRO DE 2014 que redefine a Política Nacional de Promoção da Saúde (PNPS), são: a I - a equidade, quando baseia as práticas e as ações de promoção de saúde, na distribuição igualitária de oportunidades, considerando as especificidades dos indivíduos e dos grupos; II - a participação social, quando as intervenções consideram a visão de diferentes atores, grupos e coletivos na identificação de problemas e solução de necessidades, atuando como corresponsáveis no processo de planejamento, de execução e de avaliação das ações; III - a autonomia, que se refere à identificação de potencialidades e ao desenvolvimento de capacidades, possibilitando escolhas conscientes de sujeitos e comunidades sobre suas ações e trajetórias; IV - o empoderamento, que se refere ao processo de intervenção que estimula os sujeitos e coletivos a adquirirem o controle das decisões e das escolhas de modos de vida adequado às suas condições sócio-econômico-culturais; V - a intersetorialidade, que se refere ao processo de articulação de saberes, potencialidades e experiências de sujeitos, grupos e setores na construção de intervenções compartilhadas, estabelecendo vínculos, corresponsabilidade e cogestão para objetivos comuns; VI - a intrassetorialidade, que diz respeito ao exercício permanente da desfragmentação das ações e serviços ofertados por um setor, visando à construção e articulação de redes cooperativas e resolutivas; VII - a sustentabilidade, que diz respeito à necessidade de permanência e continuidade de ações e intervenções, levando em conta as dimensões política, econômica, social, cultural e ambiental; VIII - a integralidade, quando as intervenções são pautadas no reconhecimento da complexidade, potencialidade e singularidade de indivíduos, grupos e coletivos, construindo processos de trabalho articulados e integrais; e IX - a 
territorialidade, que diz respeito à atuação que considera as singularidades e especificidades dos diferentes territórios no planejamento e desenvolvimento de ações intra e intersetoriais com impacto na situação, nos condicionantes e nos determinantes da saúde neles inseridos, de forma equânime.

Ao iniciar reflexão sobre o princípio da concepção holística, é notório que os estudantes significam a saúde como condição atrelada às suas responsabilidades, oriundas especificamente dos determinantes biológicos como hábitos alimentares e práticas de atividades físicas; foram raras as referências sobre aspectos socioeconômicos, educacionais, culturais e políticos, pressuposto apresentado na introdução que compreende a saúde como algo construído socialmente e resultado dos determinantes sociais, econômicos e culturais, desde a Carta de Otawa (BRASIL, 2002).

No entanto, essa constatação era algo esperado, pois durante o processo de mestrado, pude verificar que eu lidava com a promoção de saúde sobre outro prisma, e ao ter a oportunidade de me aproximar com os valores da promoção de saúde, verifiquei que suas respostas em muito se assemelham à forma como eu vinha conduzido minhas aulas e como estavam sendo conduzidas as tímidas ações escolares sobre a temática.

Com um olhar que se estende às suas comunidades, suas concepções de saúde inerentemente estão relacionadas à forma com que relacionam suas experiências a todas as esferas dos serviços de saúde, que provavelmente reforçaram a ideia da responsabilidade da saúde ser exclusivamente deles, recaindo sobre eles a culpa pela ocorrência ou não de agravos preveníveis, expressa em vários momentos como "eu sei que deveria...", "não sei porque não consigo ser saudável”, "sei de tudo isso, mas mesmo assim eu não consigo”.

Essa culpabilização, é esclarecida por Ferreira, et al. (2009, p. 460) ao justificá-la em um contexto, pós relatório Lalonde, com sua proposta de quatro determinantes: biologia humana, ambiente, estilo de vida e organização da assistência à saúde, que acabou gerando:

Ações centradas na mudança dos estilos de vida, produzindo, assim, um
processo de culpabilização dos pacientes (blaming the victims), com a
consequente despolitização do problema, uma vez que o Estado, através
dessa ênfase unilateral sobre os estilos de vida, joga para o nível individual
processos que têm um contorno sociopolítico mais ampliado.

Os estudantes em muitas respostas, tanto nos questionários como nas discussões, mencionaram a associação entre saúde e autopercepções positivas, como "bem-estar", "autoestima", "se sentir bem psicologicamente". Sabe-se que o período da adolescência é uma fase em que os atributos interpessoais e as habilidades sociais 
influenciam suas interações com os outros e na formação de sua autoestima, considerada um importante aspecto da qualidade de vida e bem-estar mental, pois se relaciona à satisfação, independência, adaptabilidade, liderança, resiliência ao stress e níveis altos de realizações (Fox, 1997).

Tais necessidades expostas pelos alunos e referenciadas em resultados como de Bauman et al. (2012), que indicam que fatores psicológicos (auto eficácia), culturais e sociais (suporte familiar e social) são determinantes importantes às práticas de atividade físicas, reforçam a necessidade de iniciativas escolares e comunitárias que fomentem a saúde física, mental, social e espiritual.

Essas iniciativas, de natureza complexa, trazem o princípio da intersetorialidade, como essencial para que a promoção de saúde:

\begin{abstract}
os grandes desafios da nova prática, a intersetorialidade e a interdisciplinaridade, exigem profissionais aptos ao diálogo técnico e leigo, com os mais variados setores. Professores e alunos devem se habilitar a desempenhar esta atividade e outras também, antes não requeridas, como a atuação política junto a grupos populacionais, institucionais e órgão de administração pública (Westphal, 2001, p. 2).
\end{abstract}

Um denominador comum das respostas dos estudantes foi sugerir que a escola e a comunidade poderiam "incentivar" ações em atividade física e saúde. A fim de compreender o que entendiam como "incentivo", suas respostas e discussões vinculam “incentivos" à ideia da oferta de determinadas atividades. No entanto, não trazem a intenção de que poderiam participar da escolha e de que maneira se dariam tais atividades pelo simples fato de pouco terem experimentado participar de tais decisões.

A demanda pela participação social, objetivo primordial da promoção de saúde e uma das grandes motivações desta pesquisa, enfatiza-se ao perceber que os momentos de maior entusiasmo dos estudantes foram aqueles em que se consideram pertencentes das ações e de seus espaços; ao levantarem os espaços que conheciam para práticas de atividades físicas, ao mencionarem os projetos esportivos que desenvolviam, e ao sugerirem ações diversas.

Os estudantes emitiram claramente seu desejo por mais participação dentro do processo educativo e demonstraram decepção pela ausência de projetos que tornam a escola mais dinâmica. $\mathrm{O}$ entusiasmo foi recorrentemente atrelado à intensidade de suas participações.

Torna-se muito esclarecedor o fato de que na mesma medida que anseiam por mais "incentivo", anseiam por mais participação nos processos. É interessante ressaltar que por mais que a instituição tenha oferecido participação nas questões pedagógicas, 
precisamos ainda ampliar esses canais de participação. Quando olho para minha prática docente, torna-se claro que ao continuar com a metodologia de ensino através de aulas de transmissão de informações, em nada colaborarei à construção do empoderamento de estudantes críticos e com interesse por questões políticas, movimentos sociais e outros canais de participação cidadã.

Apesar dos estudantes sugerirem algumas ações e minha intenção inicial ser de considerá-las e inclui-las em meus próximos planejamentos de ensino, a força dessas discussões possibilitou que ocorressem durante o processo desta pesquisa.

Algumas dessas atividades serão descritas de forma a ilustrar os princípios de Promoção de Saúde e verificar que apesar de serem os nossos primeiros passos, ao possibilitarmos voz aos estudantes, nos foi fornecido ferramentas para que essas ações se manifestassem, e tal motivação dos adolescentes se mostrou importante para que implantemos de fato o conceito de Escola Promotora de Saúde em nossa realidade.

Visto que temos uma horta agroecológica, fruto do Laboratório de Práticas e Estudos em Agroecologia - LAPEA, uma das sugestões dos estudantes foi de que pudéssemos realizar atividades ali; tal demanda coincidiu com a nossa II Mostra de Inovação, Pesquisa e Extensão - MIPE e dessa forma, em parceria com o colegiado do curso técnico em agroecologia, realizamos um minicurso de educação alimentar e produção de horta urbana agroecológica, para toda a comunidade escolar e externa, que repercutiu com outra realização durante a semana que se comemora o dia do servidor público, nesse momento apenas com servidores.

Ainda em parceria com o curso de agroecologia, iniciamos o Projeto Cine Saúde, uma das ações pretendidas pelo Núcleo de Estudos em Agroecologia - NEA, que faço parte, com a apresentação do documentário “O veneno está na mesa", sessão que não tivemos muitos participantes, porém gerou um debate bem interessante e pensamos para a próxima sessão divulgar melhor e com mais tempo de antecedência.

Outro momento foi a realização da trilha de caminhada e ciclística no Parque Cambuí, em que tivemos a participação de estudantes e pais interessados, foi uma manhã muito aprazível e terminamos com a sensação de que podemos e devemos aproveitar melhor aquele espaço da cidade.

Essa atividade repercutiu positivamente entre os estudantes, que formaram um grupo via whatsapp, que fui convidada a participar e conta com cerca de 20 integrantes; nele, combinam os próximos encontros e percebo que essas trilhas têm acontecido com regularidade, principalmente as de bicicleta, visto que recebo as mensagens com os 
convites, programação e horários.

Ficou estabelecido com as direções que em 2017 as aulas práticas de educação física seriam realizadas no espaço proposto da biblioteca e que seria realizada a reforma do espaço das quadras, considerada pela gestão prioridade em seu planejamento orçamentário.

As aulas, que estão sendo planejadas mediante os resultados dessa pesquisa, já estão acontecendo nesse espaço e estão sendo muito interessantes; criou-se um ambiente amplo, íntimo e confortável, onde temos o privilégio de ter inúmeros materiais propícios ao desenvolvimento de aulas de ginásticas e de exercícios funcionais e quadro flip chart para as explicações. Seus retornos têm sido muito positivos e percebo que a necessidade levantada sobre novas metodologias para se desenvolver conteúdos em saúde estão sendo pouco a pouco possibilitadas nas aulas práticas.

Em nossas discussões, em muito enaltecem os conteúdos das mídias sociais que disponibilizam vídeos de sequências de exercícios, reportagens e muitas pessoas que consideram "exemplos" saudáveis e estéticos, oportunizando assim discussões sobre padrões estéticos, fontes confiáveis de informações, bom uso da tecnologia, sexualidade, drogas, principalmente sobre o uso de ergogênicos, que lhes causam muita curiosidade.

O princípio de empoderamento em nosso contexto escolar advém da necessidade já reconhecida de criar oportunidades, autonomia, criatividade e constante participação nas decisões que cercam os estudantes.

Sinto que após nossas discussões, estamos participando em conjunto desses processos, onde tenho iniciado os primeiros passos para muni-los de experiências, físicas e conhecimentos, com o objetivo de torná-los capazes de identificar e reivindicar as injustiças e as deficiências sociais (equidade), políticas e culturais que influenciam a sua saúde e dos que o cercam.

Não conseguiria sozinha realizar tal feito, mas consigo em minha pesquisa identificar a necessidade de estratégias diferentes, destacando, portanto o princípio das ações multiestratégicas.

Quando abordados sobre aspectos da promoção de atividades físicas na escola e na comunidade, alguns resultados merecem destaque em relação aos espaços. Primeiramente ao achado de que tendem a se entusiasmar com espaços que se sintam confortáveis, que sejam próximos e que conheçam seu funcionamento.

Ações multiestratégicas são necessárias para o (re) conhecimento e 
familiarização desses espaços através de vivências em diferentes momentos e públicos diferentes, levanto a possibilidade de públicos diferentes devido ao entusiasmo aparente quando perguntados sobre aqueles locais que mais conheciam, o ato de explicar os detalhes a mim e aos seus colegas me vislumbrou a possibilidade de se tornarem em momentos oportunos e planejados agentes facilitadores desses espaços, convidando seus próximos a conhecerem outros espaços e outras comunidades.

No que diz respeito a nossa escola, foi um grande exercício de empoderamento reivindicarem a reforma do espaço, visto que têm controlado e acompanhado seu desenvolvimento através das comunicações oficiais da gestão sobre o andamento da reforma.

Participarem desse processo de acompanhamento das obras bem como termos usados outros espaços como a horta do curso de agroecologia, o parque público e termos a pretensão de usarmos outros, tornam possível desenvolvermos atividades relacionadas à educação para a manutenção dos espaços e patrimônios culturais e ecológicos. A manhã agradável que passamos durante trilha realizada com pais e estudantes me levantou também a possibilidade de realizarmos mais ações com participação dos pais, que provavelmente, têm concepções muito parecidas com as de seus filhos sobre promoção da saúde e da atividade física. E esse envolvimento dos pais no ambiente escolar não só pode contribuir com todo o processo educacional, como também à melhoria dos próprios ambientes familiares (DESSEN, 2005).

O princípio da equidade em uma escola procura minimizar as desigualdades e desenvolver os processos de ensino e aprendizagem de acordo com as necessidades de cada estudante. De uma maneira geral, mediante suas respostas, não encontrei diferenças discrepantes entre os estudantes no que diz respeito ao acesso à saúde, cuidados, acesso às políticas públicas de saúde ou espaços. Apesar de não ter levantado dados socioeconômicos, me parece que as barreiras enfrentadas, pelo menos as dialogadas, são semelhantes.

Apesar das inúmeras possibilidades de repensar a equidade em nosso contexto, terminei a pesquisa e iniciei minhas aulas com a sensação de que ainda preciso repensar e investigar sobre as diferenças sociais, econômicas e culturais que encontro em minha escola, mas a princípio o que me chamou a atenção e que tem conduzido minhas ações são as diferenças de concepções entre os gêneros.

O número de meninas na amostra foi significativamente menor do que o dos meninos, no entanto suas respostas e suas participações nas discussões tiveram uma 
presença equiparada. Pareceram-me notáveis a robustez e as preocupações com que escrevem e debatem a temática; tive esse entendimento ao me deparar com respostas mais amplas, mais complexas, em um tom mais sério e menos objetivo.

Da mesma forma que apresentam maior riqueza de informações, explicitadas quando exemplificam reportagens que leem, vídeos que assistem e pessoas que acompanham através das mídias, demonstram também maiores preocupações e ansiedades em alcançar esse status pela saúde e em buscar um padrão estético que consideram o correto, frases como "estar magra" e "emagrecer", são várias vezes associadas com estar saudável.

Considero impossível não supor que existem maiores nuances a serem exploradas no que se refere à autoimagem e às pressões exercidas pelos padrões estéticos vigentes e ao fato de que esse zelo pela saúde e pelos cuidados estéticos, desde as idades mais precoces ainda é uma preocupação predominantemente feminina, bem como pouco se interessam pelas práticas como as trilhas, os projetos, e os intervalos em que jogam algum esporte, dados que corroboram aos achados de Hallal (2012), ao descrever que a inatividade física aumenta com a idade e é maior entre o sexo feminino.

No entanto, a respeito das aulas práticas em que tenho desenvolvido principalmente exercícios funcionais em circuito, as meninas têm apresentado um nível de entusiasmo que nunca tinha me deparado e tal fato tem reforçado a ideia de seus cuidados com a saúde estarem delicadamente envolvidos com supostas inequidades durante suas vivências na educação física escolar e em questões de responsabilidades e estéticas que preciso me aprofundar.

Inequidades essas que devem ser repensadas e que vão ao encontro dos resultados da pesquisa de Alberto e Figueira Junior (2016) que ao estimar a prevalência de inatividade física em adolescentes, especificamente com as meninas, revelaram que entre os fatores socioculturais, a falta de estímulo do professor de educação física se associou com níveis insuficientes de atividade física, reforçando a ideia que temos que olhar de forma mais atenta para essa situação.

Pensar a sustentabilidade remete à possibilidade de continuidade das ações que se iniciou em nossa escola, tanto em relação à comunidade escolar, quanto trazer e fazer com que a comunidade a qual nossa escola pertence esteja sempre presente. 


\section{CONSIDERAÇÕES FINAIS}

Estando no $3^{\circ}$ bimestre do ano letivo de 2017, já não tenho a capacidade de discernir o que é minha pesquisa e o que tem sido minha prática docente, afinal, à medida que os resultados foram aparecendo e os diálogos se estreitando, me permiti numa licença poética acadêmica, testar algumas das possibilidades sugeridas pelos meus estudantes.

Os achados referentes à análise do material documental das aulas de educação física escolar proposta por essa pesquisa demostraram que os estudantes significam a saúde como condição atrelada às suas responsabilidades, oriundas especificamente dos determinantes biológicos como hábitos alimentares e práticas de atividades físicas; no entanto destacam-se as associações que realizam entre saúde e autopercepções positivas. Com vistas à promoção de saúde e da atividade física, os estudantes sugerem que à escola e à comunidade lhes cabem o papel de incentivá-los, demonstram decepção pela ausência de ações que tornam a escola mais dinâmica, apresentam entusiasmo ao identificar e explicar os espaços e ações que são familiarizados e esperam o desenvolvimento de conteúdos relacionados à saúde através de novas metodologias, principalmente as relacionadas às mídias.

Embora os resultados tenham ocorrido através do objetivo de analisar o significado que os estudantes do Instituto Federal do Paraná de Campo Largo atribuem às estratégias de promoção da saúde e da atividade física no ambiente escolar e comunitário, eles têm a capacidade de representar uma necessária reorganização escolar.

Essa reorganização que facilmente se ilustra através das reivindicações por um espaço adequado para momentos de lazer, de atividades físicas e de esportes na escola, se aprofunda quando pedem mais incentivo. Mesmo correndo o risco de ser apenas uma palavra colocada numa folha de papel ou verbalizada em uma discussão, quando um adolescente nos pede incentivo, nos coloca na posição de sermos capazes de nos aproximarmos deles.

Parece-me raso concluir pontualmente que os estudantes concebem a promoção da saúde como algo atrelado ao modelo médico de ausência de doenças e que ações democráticas são necessárias para modificar esse cenário e que bastaria o oferecimento de espaços e atividades para que houvesse promoção da atividade física, quando na realidade suas respostas refletem nossos valores sociais dominantes, de nossa cultura, de nossa época e também de suas relações com a nossa escola. Refletem minhas práticas 
educativas, mascaradas de promoção, mas que têm operado através de saberes informativos e com caráter de prevenção.

Finalizo essa pesquisa para começar uma necessária mudança que se inicia em mim, afinal, embora muito se fale sobre inclusão e empoderamento, ouvi-los foi o início da tomada de consciência de que há um abismo entre as nossas metodologias e seus contextos de vida e que não há a possibilidade de mudança sem que fomentemos suas participações, de seus familiares e de suas experiências.

O objetivo final é que possamos, os responsáveis pelo componente curricular e escola, fortalecê-los para que sejam proativos em relação à melhoria de suas condições de vida e que creditem não apenas a si, mas às relações que têm com suas comunidades a responsabilidade pelo desenvolvimento de hábitos saudáveis.

As escolas não se transformam com apenas uma ação e de maneira rápida, as escolas se tornam o que fazem com constância, numa soma de ações que, aos poucos, transformam-se em grandes mudanças. 


\section{REFERÊNCIAS}

ALBERTO, A. A. D.; FIGUEIRA JUNIOR, A . Prevalência de inatividade física em adolescentes e sua associação com variáveis socioculturais. Pensar a Prática (Online), v. 19, n.1, p. 800-813, 2016.

BARDIN, L. Análise de Conteúdo. Edições. Lisboa, LDA: Edições. 2009.

BARROS, M. V. G.; NAHAS, M. V.; HALLAL, P.C.; FARIAS JUNIOR, J. C.; FLORINDO, A. A.; BARROS, S. S. H. Effectiveness of a school-based intervention on physical activity for high school students in Brazil: The Saude na Boa Project. J Phys Act Health, v. 2, p. 163-169, 2009.

BAUMAN, A. E.; REIS, R. S.; SALLIS, J. F.; WELLS, J. C.; LOOS, R. J. F. ; MARTIN, B. W. Correlates of physical activity: why are some people Physically active and others not? Lancet, v. 380, n. 9838, p. 258-271, 2012.

BRASIL. Ministério da Saúde. Promoção da Saúde: Declaração de Alma-Ata, Carta de Otawa, Declaração de Adelaide, Declaração de Sundsvall, Declaração de Santafé de Bogotá, Declaração de Jacarta, Rede de Megapaíses e Declaração do México. Brasília, 2001.

Lei $\mathbf{n}^{\mathbf{0}} \mathbf{1 0 . 7 9 3}$ de 1 de dezembro de 2003. Altera a redação do art. 26, § $3^{\circ}$, e do art.92 da Lei $n^{\circ}$ 9.394, de 20 de dezembro de 1996, que "estabelece as diretrizes e bases da educação nacional", e dá outras providências. Brasília, DF. Disponível na Internet: http://www.planalto.gov.br/.

Comissão Nacional sobre Determinantes Sociais da Saúde. As causas sociais sobre as iniquidades em saúde no Brasil. Rio de Janeiro, 2008.

CORREIA, W.R. Planejamento Participativo e o Ensino de Educação Física no $2^{\circ}$ Grau. Revista Paulista de Educação Física, São Paulo, Supl. 2, p. 43-48, 1996.

DESSEN, M. A.; COSTA JUNIOR, A. L. A ciência do desenvolvimento humano: tendências atuais e perspectivas futuras. Porto Alegre: Artmed, 2005.

DUCA, G.F.D.; BARROS, M.V.G.; SILVA, K.S.; GARCIA, L.M.T.; BEZERRA, J.; NAHAS, M. V. Intervention to promote physical activity in high-school students: effectiveness on active commuting, strength exercises and stages of behavior change. Rev. Bras. Cineantropom. Desempenho Hum, v. 16, suppl.1, p. 13-24, 2014.

FERREIRA NETO, J. L., KIND, L., BARROS, J. S., AZEVEDO, N. S., ABRANTES, T. M. Apontamentos sobre promoção da saúde e biopoder. Saúde e Sociedade, v. 18, n. 3, 456-466, 2009.

GANDIN, D. A Posição do Planejamento Participativo entre as Ferramentas de intervenção na Realidade. Currículo sem Fronteiras, v.1, n.1, 81-95, 2001. 
HALLAL, P.C.; BAUMAN, A.E.; HEATH, G.W.; KOHL, H.W.; LEE, I.-M.; PRATT, M. Physical activity: more of the same is not enough. Lancet, v. 380, n. 9838, p. 190-191, 2012.

LEE, M. I.; SHIROMA, E. J.; LOBELO, F. Effect of physical inactivity on major non-communicable diseases worldwide: an analysis of burden of disease and life expectancy. Lancet, v. 380, n. 9838, p. 219-229, 2012.

LIMA, A. L. G. S.; PINTO, M. M. S. Fontes para a história dos 50 anos do Ministério da Saúde. Hist. Cienc. Saúde-Manguinhos. 2003;10: 1037-51.

MACLAREN, L., HAWE, P. Ecological perspectives in health research. J epidemiol Community Health. v. 59, n. 1, p. 6-14, 2005.

MOREIRA, M.A. Teorias de aprendizagem. São Paulo: EPU, 2009.

OLIVEIRA, D. C. Análise de Conteúdo Temático Categorial: Uma proposta de sistematização. Rev. Enferm. UERJ, Rio de Janeiro, 2008 out/dez; 16(4):569-76.

ORGANIZACION PANAMERICANA DE LA SALUD. EI movimento de Municipios Saludables: uma Estrategia para la Promoción de la salud en América Latina. Washington, D.C; Organizacion Panamericana de la Salud; ago. 1996. $17 \mathrm{p}$.

PACHECO, E. Perspectivas da educação profissional técnico de nível médio: propostas de diretrizes curriculares. São Paulo: Moderna, 2012.

PELICIONI, M. C. F; TORRES, A.L. A Escola Promotora de Saúde. São Paulo: Deártamento de Práticas de Saúde Pública, 1999.

RIBEIRO, E. H.; FLORINDO, A. A. Efeitos de um programa de intervenção no nível de atividade física de adolescentes de escolas públicas de uma região de baixo nível socioeconômico: descrição dos métodos utilizados. Revista Brasileira de Atividade Física e Saúde, v. 15, n. 1, p. 28-34, 2010.

RICHARD L, POTVIN L, MANSI O. The Ecological approach in health promotion programmes: the views of health promotion workers in Canada. Health Education Journal, v. 57, n. 2, p. 160-73, 1998.

SCHMIDT, M. I.; DUNCAN, B. B.; SILVA, G. A.; MENEZES, A. M.; MONTEIRO, C. A.; BARRETO, S. M.; CHOR, D.; MENEZES, P. R. Health in Brazil 4. Chronic non-communicable diseases in Brazil: burden and current challenges. Lancet, n. 377, 2011.

SÍCOLI, J. L., NASCIMENTO, P. R. Health promotion: concepts, principles and practice. Interface - Comunic, Saúde, Educ, v.7, n.12, p.91-112, 2003.

THØGERSEN-NTOUMANIS, C.; FOX, K.R.; NTOUMANIS, N. Relationships between exercise and three components of mental well-being in corporate employees. Psychology of Sport and Exercise, n. 6, p. 609-627, 2005. 
UNIVERSIDADE DE SÃO PAULO. Sistema de Integrado de Bibliotecas.

Diretrizes para apresentação de dissertações e teses da USP: documento eletrônico e impresso. 2. ed. rev. e ampl. São Paulo: SIBi/USP, 2009. 4 v. Parte I (ABNT); Parte II (APA); Parte III (ISO) e Parte IV (Vancouver). Disponível em:

$<$ http://www.teses.usp.br/index.php?option=com_content\&view=article\&id=52\&Ite mid=67\&lang=pt-br $>$. Acesso em: 10 jun. 2015.

WANG, H. H.; WU, S. Z.; LIU, Y. Y. Association between social support and health outcomes: a meta-analysis. The Koahsiung Journal of Medical Sciences, Kaohsiung, v. 19, n. 7, p. 345-351, 2003.

WESTPHAL, M. F. A Nova Saúde Pública. Jornal da USP - Universidade de São Paulo, XV, 545, 2, 2010.

WHO. Global recommendations on physical activity for health. World Health Organization; 2010

WHO. Health promotion evaluation: recommendations to policymakers. Copenhagen: European Working Group on Health Promotion Evaluation, 1998. 


\section{ANEXO A - QUESTIONÁRIO DE PROMOÇÃO DE SAÚDE E ATIVIDADE FÍSICA}

Mediante os conceitos:

Ambiente escolar: Conjunto de pessoas e espaços envolvidos diretamente no processo educativo, composto por professores, alunos e por outros profissionais.

Comunidade: 1. Qualidade daquilo que é comum. 2. Agremiação. 3. Comuna. 4. Sociedade. 5. Identidade. 6. Paridade. 7. Conformidade. 8. Lugar onde vivem indivíduos agremiados.

Saúde: Estado positivo. Bem-estar bio-psicossocial e espiritual; Realização das aspirações e atendimento de necessidades.

Atividade Física: Qualquer movimento corporal, produzido pelos músculos esqueléticos, que resulta em gasto energético maior do que os níveis de repouso (prática de esporte, exercício físico e as práticas corporais).

Responda por gentileza às questões:

1. O que deve ser realizado para promover a saúde de adolescentes no ambiente escolar?

2. O que deve ser realizado para promover a atividade física de adolescentes no ambiente escolar?

3. O que deve ser realizado para promover a saúde de adolescentes na sua comunidade?

4. O que deve ser realizado para promover a atividade física de adolescentes na sua comunidade? 